\title{
Operación masacre
}

Guión teatral de Jorge Curi y Mercedes Rein (1973), basado en el libro testimonial de Rodolfo Walsh

Edición crítica de Victoria García (UBA/CONICET)

Operation Massacre. Theatrical play by Jorge Curi and Mercedes Rein (1973), based on the non-fiction novel by Rodolfo Walsh.

Edition by Victoria García (UBA/CONICET)

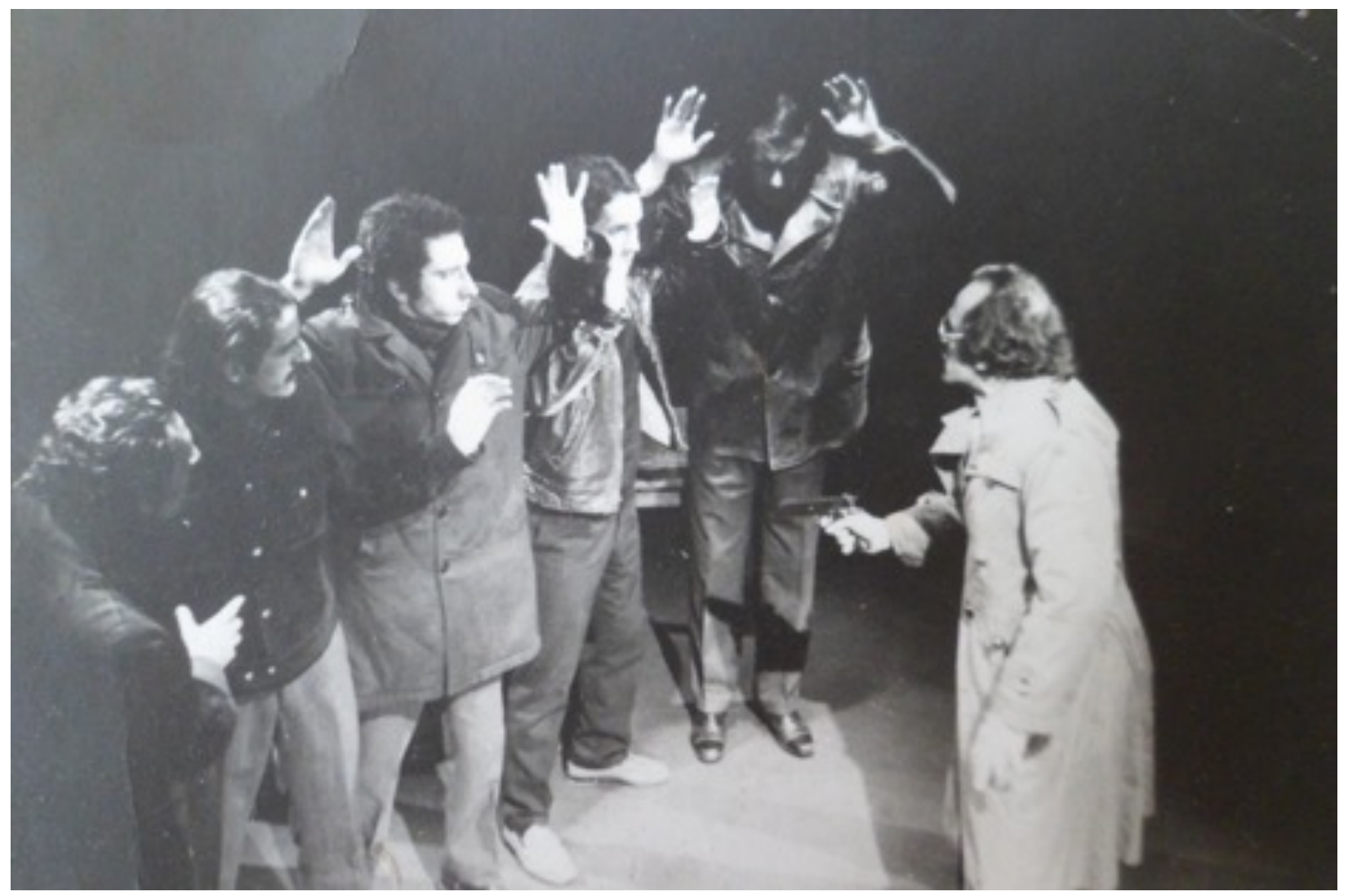




\section{Introducción}

El 21 de julio de 1973 se estrenó en el Teatro Circular de Montevideo Operación masacre, obra basada en el libro testimonial de Rodolfo Walsh, con guión de Mercedes Rein y Jorge Curi, y dirección de este último. Las representaciones comenzaron pocas semanas después del golpe de Estado que dio inicio en Uruguay a la dictadura militar que se extendería hasta la década siguiente. La puesta constituyó, así, una expresión del teatro de resistencia uruguayo en el contexto dictatorial. Centrada en un episodio de represión política en la Argentina de la 'Revolución Libertadora', la obra denunciaba toda una historia represiva en Latinoamérica, que llegaba hasta la actualidad uruguaya de los primeros años 70.

El texto de Walsh, que para 1973 era conocido como referente de la literatura testimonial latinoamericana, proveyó una base ineludible para la dramaturgia. Esta, no obstante, fue un proceso específicamente teatral, que incluyó la reapropiación creativa de dos importantes tradiciones estéticas vinculadas con la significación histórica y política del arte: el teatro épico de Brecht, por un lado, y el teatro documental a la manera en que lo desarrollaba Peter Weiss, por otro. De la estética brechtiana, Operación masacre tomó la práctica del distanciamiento: la escena exhibía su propia teatralidad, en recursos como la ruptura de la correlación directa entre actor y personaje (cada miembro del elenco representaba a varios personajes), la exposición de la sucesión de escenas mediante carteles, las expresiones meta-teatrales incluidas en el guión y la desnaturalización del tiempo-espacio escénico (la historia no se contaba en forma lineal, sino que se superponía el tiempo-espacio de los hechos con el de la investigación y el del presente del espectáculo). En cuanto al teatro documental, la adaptación de Curi y Rein recuperó de esa vertiente dramatúrgica la teatralización de hechos reales, la sobriedad de la escena, el trabajo con la palabra de las víctimas y la incorporación de documentos históricos en la representación teatral ${ }^{1}$.

La obra dirigida por Curi es un material relevante desde el punto de vista de la historia del testimonio en Latinoamérica. Permite considerar la expansión del testimonio y del documento en el campo artístico latinoamericano de los años 60-70, que involucró a la literatura pero también a las artes visuales, el cine y el teatro. En este último lenguaje artístico, el haber estado allí característico del discurso testimonial no toma la forma de un relato sobre el pasado -como ocurre en el texto literariosino, más bien, de un acontecimiento: los hechos y sus protagonistas pasan a estar allí, encarnados en los actores y re-presentados en la escena teatral.

\footnotetext{
${ }^{1}$ Para un análisis pormenorizado de la puesta de Operación masacre, y de su significado en el campo artístico de los años 70 , remitimos los trabajos de Mirza (2007a: 141 y ss.; 2007b: 114) y a nuestro propio enfoque (García, 2014). En cuanto al teatro documental como corriente dramatúrgica en Latinoamérica, reenviamos al panorama histórico que ofrece BravoElizondo (1979 y 1982).
} 
El guión de Operación masacre que presentamos a continuación se encontraba inédito hasta este momento. Con su publicación en este número de Kamchatka. Revista de análisis cultural, buscamos contribuir a la difusión de un documento significativo en la historia del arte testimonial y documental en la América Latina contemporánea.

\section{Acerca de la presente edición}

El texto que publicamos corresponde al libreto utilizado por los partícipes de la puesta de Operación masacre, durante el proceso dramatúrgico ligado a la obra teatral. Hemos considerado el texto mecanografiado de la adaptación de Jorge Curi y Mercedes Rein como base para la edición, y complementado dicho texto básico con la transcripción -en notas al pie- de enmiendas realizadas a mano sobre el libreto original. De esta manera, procuramos ofrecer a los lectores un documento que dé cuenta de algunas de las decisiones dramatúrgicas que conllevó la construcción de un guión para su interpretación teatral a partir del libro de Rodolfo Walsh. El texto no pretende constituir un reflejo fiel de las representaciones de Operación masacre en el Teatro Circular de Montevideo: así como las enmiendas manuscritas exponen modificaciones del texto inicial de la adaptación, ciertos materiales de archivo vinculados a la obra muestran que tampoco la que se encuentra en las enmiendas fue la versión definitiva del espectáculo ${ }^{2}$. En rigor, no hay transcripción que contenga por sí sola la complejidad asociada al acontecimiento teatral, y a las múltiples dimensiones semióticas que se ponen en juego en la escena. No obstante, el texto es un material insoslayable para reconstruir el proceso dramatúrgico asociado a la teatralización de Operación masacre.

Para la presente edición, hemos normalizado la ortografía y la puntuación del libreto original, y hemos reemplazado las abreviaturas por palabras completas, incluso en la especificación de los nombres de los personajes correspondientes a cada una de las intervenciones habladas, que en el libreto se encuentran designados por iniciales.

La publicación de este documento no habría sido posible sin la colaboración generosa de Carlos Frasca, uno de los actores de la obra, que aportó el libreto y distintas fuentes de archivo que contribuyen a establecer las características de la puesta teatral. Hemos contado con su inestimable ayuda, así como con la autorización de Jorge Curi, para editar este material.

\footnotetext{
${ }^{2}$ En particular, hemos cotejado el texto que presentamos con la grabación de audio de una de las funciones del espectáculo, y observamos cambios entre una y otra versión del guión.
} 


\section{Bibliografía}

Bravo-Elizondo, Pedro. “La realidad latinoamericana y el teatro documental”. Texto crítico 5-12 (1979): 200-210.

Bravo-Elizondo, Pedro (1982). Teatro documental latinoamericano I. México: UNAM.

García, Victoria (2014). "El pueblo en la escena latinoamericana. Sobre la transposición al teatro de Operación masacre, de Rodolfo Walsh (Montevideo, 1973)". Actas del VII Seminario Internacional Políticas de la memoria, "Presente y tradición del pensamiento emancipatorio". Ministerio de Justicia y Derechos Humanos, Centro Cultural de la Memoria Haroldo Conti.

Mirza, Roger (2007a). La escena bajo vigilancia: teatro, dictadura y resistencia. Montevideo: Ediciones de la Banda Oriental.

Mirza, Roger (2007b). "Productividad del modelo brechtiano en el teatro uruguayo contemporáneo". Pelletieri, Osvaldo (ed.). Huellas escénicas. Buenos Aires, Galerna: 107-118. 


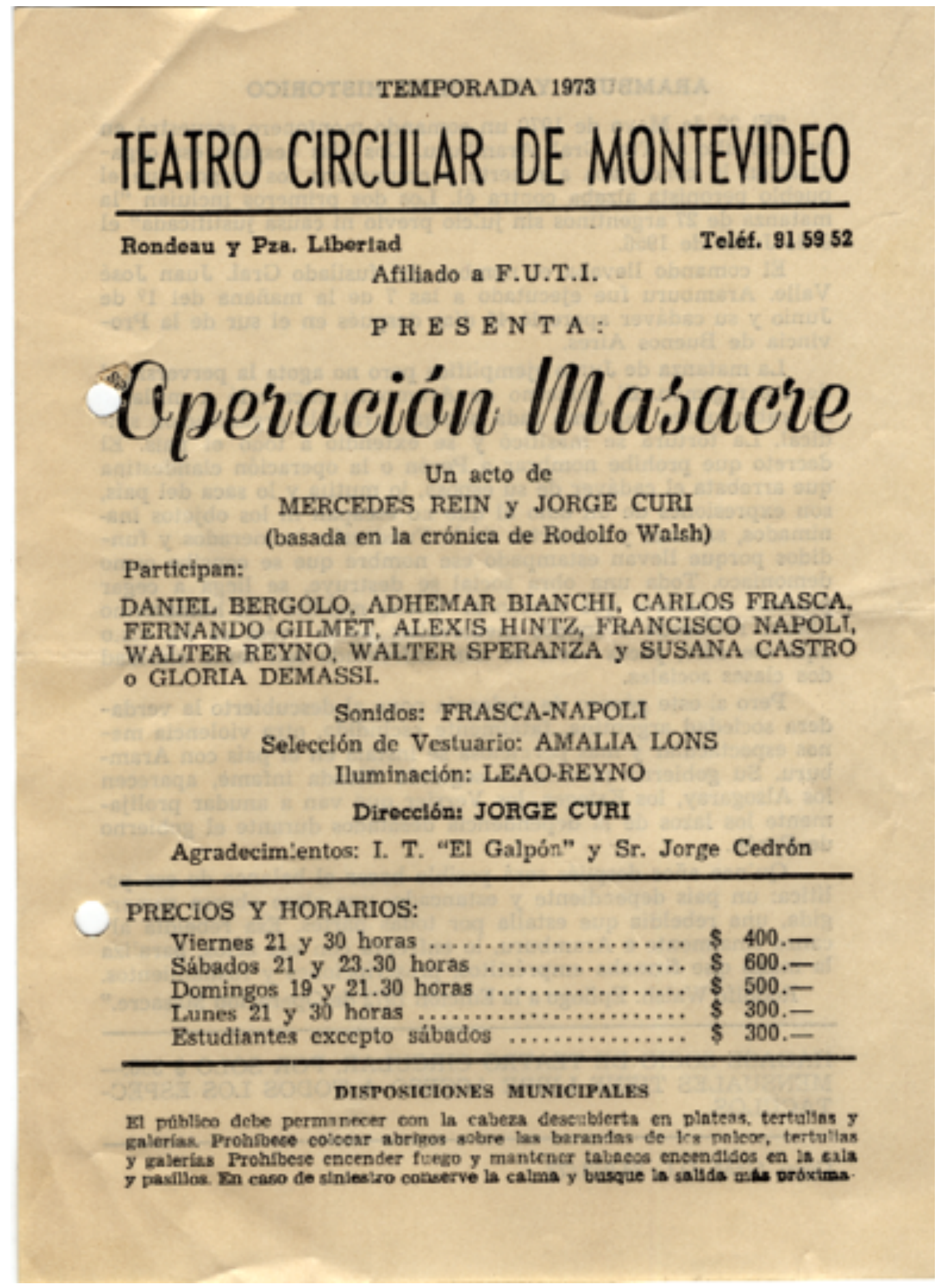

AVATARES DEL TESTIMONIO EN AMÉRICA LATINA 


\section{ARAMBURU Y EL JUICIO HISTORICO}

"E1 29 de Mayo de 1970 un comando montonero secuestró en su domiellio al Tte. Gral. Aramburu. Dos días después esa organización lo condenaba a muerte y enumeraba los cargos que el pueblo peronista alzaba contra él. Los dos primeros incluian "la matanza de 27 argentinos sin juicio previo ni causa justificada" el 9 de Junio de 1956.

El comando llevaba el nombre del fusilado Gral. Juan José Valle. Aramburu fue ejecutado a las 7 de la mañana del $1^{\circ}$ de Junio y su cadáver apareció 45 dias después en el sur de la Provincia de Buenos Aires.

La matanza de Junio ejemplifica pero no agota la perversidad de ese régimen. El gobierno de Aramburu encarceló a millar de trabajacores, repramió cada huelga, arrasó la organización sindical. La tortura se masificó y se extendió a toco el pais. E1 decreto que prohibe nombrar a Pcrón o la operación clandestina que arrebata cl cadáver de su esposa, lo mutila y lo saca del país, son expresiones de un odio al que no escapan ni los objetos inanimados, sábanas y cubiertos de la Fundación incinerados y fundidos porque llevan estampado ese nombre que se concibe como demoniaco. Toda una obra social se destruye, se llega a cegar piscinas populares que evocan el "hocho maldito", el humanismo liberal retrocede a fondos medievales; pocas veces se ha vis.o aquí ese odio, pocas veces se han enfrentado con tanta claridad dos clases sociales.

Pero si este género de violencia pone al descubierto la verdadera sociedad argentina, fatalmente escindida, otra violencia menos espectacular y más perriciosa se instala en el país con Aramburu. Su gobierno modela la segunda década infame, aparecen los Alsogaray, los Krieger, los Verrier que van a anudar prolijamente los lazos de la dependencia desatados durante el gobierno de Perb́n.

Quince años después será posible hacer el balance de esa politica: un pais deperdiente y estaneado, una clase obrera sumergida, una rebeldia que estalla por todas partes. Esa rcbeldia al canza finalmente a Aramburu, to enfrenta con sus actos, paraliza la-mano que firmaba empréstitos, proseripciones y fusilamientos.

Rodolfo Walsh. Epilogo a la Edición 1972 de Operación Masacre."

HAGASE SOCIO DE TEATRO CIRCULAR. POR SOLO \$ $300-$ MENSUALES TIENE LIBRE ACCESO A TODOS LOS ESPECTACULOS.

Corp. Gráf. D.L. $34.943 / 73$ 


\section{Operación Masacre}

Guión teatral de Mercedes Rein y Jorge Curi, basado en el libro testimonial de Rodolfo Walsh. ${ }^{3}$

Teatro Circular de Montevideo, 1973

-Buenas noches. Esto no es exactamente un espectáculo.

-Vamos a contarles una historia, una historia real.

-Se trata de hechos que ocurrieron hace algunos años -exactamente diecisiete años- en la República Argentina.

-Cada vez que volvemos a decir los nombres: Livraga, Giunta, Horacio Di Chiano...

-Carranza, Rodríguez, Carlitos Lizaso...

-Torres, Gavino, Mario Brión, vuelve sobre nosotros la larga noche del 9 de junio.

-Él representa al periodista Rodolfo Walsh. Empezamos ${ }^{4}$.

WaLSH: Mi nombre es Rodolfo Walsh. Soy argentino. Periodista. Escribo cuentos policiales, juego al ajedrez; tal vez, algún día pueda escribir la novela seria que vengo planeando desde años. Mientras tanto, para ganarme la vida, hago cosas que llamo periodismo, aunque no es periodismo. La violencia me ha salpicado las paredes de mi casa, en las ventanas hay agujeros de bala, he visto un coche agujereado y dentro un hombre con los sesos al aire, pero es solamente el azar lo que me ha puesto eso ante los ojos.

El 9 de junio de 1956, en la ciudad de La Plata yo estaba a medianoche en un café donde se jugaba al ajedrez, cuando nos sorprendió el cercano tiroteo con que empezó el asalto al comando de la Segunda División y al departamento de policía, en la fracasada revolución de Valle.

Recuerdo que esa misma noche, horas más tarde pegado a la persiana de mi habitación oí morir a un conscripto en la calle y ese hombre no dijo: "Viva la patria" sino:

-“No me dejen solo, hijos de puta”.

\footnotetext{
${ }^{3}$ Esta obra está sujeta a derechos de autor. Cualquier representación deberá contar con el permiso de los autores.

${ }^{4}$ El guión contiene algunos pasajes en los que no se especifican los nombres de los personajes que intervienen en cada caso. En este segmento inicial, ello se debe a que el comienzo de la obra no estaba protagonizado, en rigor, por personajes, sino por los mismos actores que (re)presentaban la representación.
} 
WALSH: La primera noticia de los fusilamientos clandestinos de junio de 1956, me llegó en forma casual a fines de ese mismo año. Una noche asfixiante de verano, frente a un vaso de cerveza un hombre me dice:

-Hay un fusilado que vive.

WALSH: No sé por qué pido hablar con él, por qué estoy hablando con Juan Carlos Livraga. Pero después sé. Miro esa cara, el agujero en la mejilla, el agujero más grande en la garganta, la boca quebrada y los ojos opacos donde se ha quedado la sombra de la muerte. Me siento insultado como cuando oí aquel grito desgarrador detrás de la persiana.

Lo que sabe Livraga es que eran unos cuantos y los llevaron a fusilar, que eran como diez y los llevaron, y que él y Giunta están vivos. Así nace esta investigación. La larga noche del 9 de junio vuelve sobre mí; por segunda vez me saca del mundo normal, de las horas tranquilas.

Ahora, durante casi un año no pensaré en otra cosa, abandonaré mi casa y mi trabajo, me ${ }^{5}$ llamaré Francisco Freire, tendré una cédula falsa con ese nombre. Un amigo me prestará una casa en el Tigre, durante dos meses viviré en un helado rancho de Merlo, llevaré conmigo un revólver, y a cada momento las figuras del drama volverán obsesivamente: Livraga bañado en sangre, caminando por aquel interminable callejón por donde salió de la muerte, y el otro que se salvó con él, disparando por el campo entre las balas, y los que se salvaron sin que él supiera y los que no se salvaron.

Esta es la historia que escribo en caliente y de un tirón para que no me ganen de mano, pero que después se va arrugando día a día en un bolsillo, porque la paseo por todo Buenos Aires y nadie me la quiere publicar, y casi ni enterarse.

Así que ambulo por suburbios cada vez más remotos del periodismo hasta que al fin recalo en un sótano de Leandro Alem donde se hace una hojita gremial y encuentro un hombre que se anima. Temblando y sudando porque él tampoco es un héroe de película sino simplemente un hombre que se anima, y eso es más que un héroe de película. Hay otros que me ayudan. Ante todo una muchacha que es periodista, se llama Enriqueta Muñiz y se juega entera. Juntos realizamos esta investigación.

MUJER: Es cosa de reírse, a diecisiete años de distancia, porque se pueden revisar las colecciones de los diarios de entonces y esta historia no existió ni existe.

WALSH: Pero la evidencia consta por escrito en documentos irrefutables.

5 Tachado a mano desde aquí y hasta “... un revólver”. 
MUJER: La palabra de los testigos, las denuncias, los interrogatorios, todo ello consta en las actas judiciales de un proceso que quedó trunco: el proceso de la operación masacre.

$\mathrm{OFF}^{6}$ : Se va a dar lectura a un comunicado de la secretaría de prensa de la presidencia de la Nación:

"Considerando que la situación provocada por elementos perturbadores del orden público 7 , obliga al gobierno provisional a adoptar con serena energía ${ }^{8}$ las medidas adecuadas para asegurar la tranquilidad pública, en todo el territorio de la Nación ${ }^{9}$, así como el normal cumplimiento de las finalidades de la Revolución Libertadora ${ }^{10}$ por ello el presidente provisional de la Nación Argentina, en ejercicio del poder Legislativo ${ }^{11}$, decreta en forma de ley:

“Art. $1^{\circ}$ - Declárase en vigencia la ley marcial en todo el territorio de la Nación.

“Art. $2^{\circ}$ - El presente decreto-ley será refrendado por el excelentísimo señor Vice-presidente provisional $^{12}$ de la Nación y los señores ministros ${ }^{13}$ secretarios de Estado, en los departamentos ${ }^{14}$ de Aeronáutica, Ejército, Marina e Interior”.

(El texto siguiente se intercalará o montará con los artículos del decreto).

-La policía

-¿Qué pasa?

-¿Dónde está Tanco?

-La revoluzione, la revoluzione ${ }^{15}$.

-Llévenselos para el auto.

\footnotetext{
${ }^{6}$ Anotación al margen: “1”. Es la primera de una serie de diecisiete llamadas mediante las cuales, a lo largo de todo el guión, se señalan los momentos de la representación en los cuales interviene el sonido en off. La especificación correspondiente a esta primera llamada, asimismo consignada a mano, es: "Se va a dar lectura... (collage) (sirena)".

${ }^{7}$ Acotado a mano: “(1)”. Indica la primera de una serie de ocho intercalaciones de texto que se realizan durante la lectura del comunicado de prensa y los decretos, y que se especifican al dorso de la hoja anterior del guión. La intercalación que aquí corresponde es: "(1) Chau, don Carranza”.

${ }^{8}$ Igual que en el caso anterior, superíndice anotado a mano: “(2)”. Indica la intercalación de: “(2) Fría la noche, ¿eh?”.

${ }^{9}$ Acotado a mano: “(3)”. Indica la intercalación de: “(3) Por favor, cuidate”.

${ }^{10}$ Acotado a mano: “(4)”. Indica la intercalación de: “(4) Todo Buenos Aires lo sabía”.

${ }^{11}$ Acotado a mano: “(5)”. Indica la intercalación de: “(5) Aquel sábado 9 de junio”.

12 Acotado a mano: “(6)”. Indica la intercalación de: “(6) Yo creo que nos matan”.

${ }^{13}$ Acotado a mano: “(7)”. Indica la intercalación de: "(7) Por favor, cuidate”.

${ }^{14}$ Acotado a mano: “(8)”. Indica la intercalación de: “(8) Corré, Lizaso, corré”.

15 Añadido a mano con una flecha: “Art. $1^{\circ}$ ”.
} 
-¿Para qué nos llevan?

Art. $1^{\circ} 16$.

¿¿Qué nos van a hacer?

-Caminen para adelante.

-Nosotros somos inocentes.

-No les vamos a hacer nada ${ }^{17}$.

Art. $2^{\circ}$.

-Vamos, caminen.

-Por favor...

-No tengan miedo. Yo creo que nos matan.

-De frente y codo con codo.

- Por mis hijos...

Art. $3^{\circ}$. Dé forma

-¡Fuego!

¡¡Por mis hijos!

-¡Tírenles!

-¡Mátenme! ¡No me dejen así! ¡Mátenme!

-Firmado: Aramburu-Rojas-Hartung-Krausp-Osorio Arana- Landaburu.

MUJER: Les dijeron: "No les vamos a hacer nada"18.

WALSH: La revolución de Juan José Valle fue sólo un episodio de las luchas que sucedieron a la caída de Perón. Nueve meses antes, en el año 1955, la revolución Libertadora había unido contra el peronismo a radicales y conservadores bajo el lema del "Imperio del derecho". Sobre ese lema, entre otras cosas queremos hablar esta noche. "Imperio del derecho".

16 Tachado y corregido a mano: "Texto":

${ }^{17}$ En la línea siguiente se lee “Art $1^{\circ}$ ”, mecanografiado y luego tachado a mano.

18 Anotada a mano, segunda llamada de sonido en off, “2”. La especificación correspondiente es: "Proclama Valle”. 
OFF: “El país vive una cruda y despiadada tiranía. Se persigue, se encarcela ${ }^{19}$, se excluye de la vida cívica a la fuerza mayoritaria”.

MujER: Así rezaba la proclama firmada por los generales peronistas Valle y Tanco en junio de 1956.

OFF: "Se ha abolido la constitución para liquidar el artículo $4^{\circ}$ que impedía la entrega al capitalismo internacional de los servicio públicos y las riquezas naturales".

-Se pretende someter a los obreros por hambre, "a la voluntad del capitalismo, y retrotraer al país al más crudo coloniaje mediante la entrega al capitalismo internacional, de los resortes fundamentales de su economía”.

WALSH: La proclama de Valle ilustraba los dos aspectos que en aquellos tiempos iniciales de la resistencia, caracterizaban al peronismo: una obvia aptitud para percibir los males que sufren en forma directa, en cuanto a fuerza popular mayoritaria, y una notable ambigüedad para diagnosticar las causas, convertirse en movimiento revolucionario de fondo y abandonar definitivamente al enemigo, las consignas electorales y las bellas palabras.

Por supuesto, Valle actuó, y entregó su vida, y eso es mucho más que cualquier palabra. La historia de su levantamiento es corta. Entre el comienzo de las operaciones y la reducción del último foco revolucionario, transcurren menos de doce horas.

A la hora 2.53 del día 10 de junio de 1956, la cadena nacional de radiodifusión ha conectado con el despacho del vicepresidente de la Nación, contraalmirante Rojas, y éste en persona lee el comunicado $\mathrm{N}^{\circ} 2$, informando que se ha dominado el motín de la escuela de Mecánica del Ejército.

OFF: Que nadie se equivoque. La Revolución Libertadora cumplirá inexorablemente sus fines ${ }^{20}$.

MujER: Son muchos los fusilados. Civiles y militares. En menos de setenta y dos horas, suman veintisiete ejecuciones.

WALSH: El 12 de junio se entrega el general Valle, a cambio de que cese la matanza. Lo fusilan esa misma noche.

Mujer: Pero no es su caso el que hoy nos ocupa, sino un hecho que afecta a un grupo de civiles, individuos comunes y corrientes, como usted y como yo, cuyos nombres no registra la historia,

\footnotetext{
${ }^{19}$ Añadido a mano: "se confina”.

${ }^{20}$ Tercera llamada sobre sonido en off, “3”. Corresponde: "Que nadie se equivoque”.
} 
cuyas huellas, en parte se han borrado, pero que un día entraron en el engranaje de la justicia vigente, bajo el Imperio del Derecho.

WALSH: Vamos a designar a las personas por sus nombres verdaderos. Todas ellas existieron, como usted y como yo. Y algunos están muertos ${ }^{21}$.

\section{SÁBADO 9 DE JUNIO DE 1956}

MuJER: Juan Carlos Livraga, el fusilado que vive, estaba por cumplir 24 años en junio de 1956. Hijo de un constructor, trabajaba de colectivero.

WALSH: No fue fácil ubicarlo, hablar con él. Livraga quiere que se sepan los hechos. Es el único entre los sobrevivientes que se atreve a presentar una denuncia ante la justicia. Me cuenta su historia increíble. La creo en el acto.

LIVRAGA: Esa noche volví temprano a mi casa.

WALSH: ¿Por qué? ¿Sabía que se preparaba algo?

LIVRAGA: ¿Qué iba a saber? Se me descompuso el colectivo y por eso me fui para mi casa.

WALSH: ¿No había oído ningún rumor sobre la sublevación que preparaban los generales peronistas?

Livraga: Yo no sé nada de política. Me fui a un café de la avenida San Martín y pensaba quedarme a jugar al billar. Pero me encontré con un amigo, Vicente Rodríguez. Hablamos de la pelea a la noche, entre el campeón Lausse y el chileno Loayza.

\footnotetext{
21 Anotaciones al margen: "Música preludio" y “4”. El número es la cuarta llamada sobre sonido en off, correspondiente a "Preludio".
} 
RoDRíGUEZ ${ }^{22}$ : Si querés, podemos escuchar la pelea en casa de un amigo, un tal Torres; vive acá a la vuelta, en la calle Yrigoyen.

Livraga: Bueno, vamos. ( Walsh). Yo, a ese Torres, ni siquiera lo conocía. Imagínese, si no me encuentro con el Gordo, no le estaría contando ahora todo esto. En fin, entramos. Era un departamento modesto, al fondo de un largo pasillo. Había bastante gente escuchando la radio, jugando a las cartas. El gordo me dijo:

RODRÍGUEZ: Aquí viene cualquiera. La puerta está abierta para todo el mundo.

LiVRaGa: ¡Pobre Gordo! Si hubiera querido, los desparramaba a trompadas a los milicos. Pero, ¿qué sabíamos? Cuando cayó la policía ni siquiera se nos ocurrió resistir.

MuJER: ¿Qué sabe sobre Vicente Rodríguez? Que tenía treinta y cinco años, que cargaba bolsas en el puerto, que grandote y pesado como era, jugaba al fútbol como un chiquilín.

WALSH: Y no estaba conforme con su suerte. Pero no sabía que terminaría mordiendo el pasto de un potrero, pidiendo por favor que lo matasen, que acabaran de matarlo, revolcándose tratando de tragarse la muerte, el plomo que no acababa de llenarlo por los agujeros de bala de Mauser que le perforaban todo el cuerpo.

\footnotetext{
${ }^{22}$ El diálogo entre Rodríguez y Livraga, breve en el texto mecanografiado, se amplía en anotaciones manuales al dorso:

"Rodríguez: Si querés podemos escuchar la pelea en casa de un amigo. Un tal Torres. Vive acá a la vuelta en la calle Yrigoyen./ Livraga: ¡Estás loco! Si no lo conozco. ¿Qué va a decir la familia?/ Rodríguez: No tiene familia. Alquila una pieza en los fondos del viejo Di Chiano. Se entra directo por un corredor. El loco Torres es flor de tipo. Todo el mundo lo conoce. Los muchachos van a jugar a las cartas, hacen asados. / Livraga: Y bueno, por mí no hay problema. Total hoy es sábado./ Rodríguez: Pucha, que son largas las noches de... sábado. Eh, pibe, ¿andás en banderola hoy?/ Livraga: ¿Y qué querés si se me rompió el colectivo? ¿Te tomás otra? / Rodríguez: No, me pudre este café. Siempre igual, la grapa cada vez peor./ Livraga: Hay días que -mirá- más vale no salir a la calle. Hoy casi le doy un tortazo a una vieja. ¿Vos sabés cómo me tienen los viejos? Porque no aflojan, che. Prefieren pasarse tres cuadras para seguirte la discusión. Hoy por culpa de una casi reviento a un ciclista. ¿Sabés cómo le metí los frenos? Lo único bueno es que la vieja se cayó de culo. Yo no lo toqué al ciclista. Apenas le torcí una rueda. Pero, un escombro. Vino un milico... Vos sabés cómo me tienen los milicos. Peor que las viejas, con eso te digo todo./ Rodríguez: Me lo vas a decir a mí./ Livraga: ¿A vos qué?/ Rodríguez: ¿No sabés que se nos metieron en el puerto? Nos deshicieron el sindicato. Los milicos, sabés cómo, hasta en la sopa me los encuentro./ Livraga: Y bueno, a ellos los mandan./ Rodríguez: Así que los defendés./ Livraga: Yo no defiendo nada./ Rodríguez: Así que los defendés, ¿eh? Les das la razón, claro./ Livraga: ¿Quién les da la razón? No me jodas, gordo. Yo a los milicos los mando a todos a la gran puta si me da la gana, entendés./ Rodríguez: Pero che, ¿por qué me gritás? Ahora te la agarrás conmigo./ Livraga: No, gordo. Dale, vos sos tierno en el fondo./ Rodríguez: Te la agarrás conmigo también./ Livraga: Dale, gordo, acabala. Vamos a escuchar la pelea./ Rodríguez: Está bien, vamos".
} 
MujER: Su mujer le decía: “tené cuidado, Vicente. No te metás en líos. Pensá en tus hijos”"23.

Pero Rodríguez quería otra vida para sus hijos. Pero era un carácter alegre, bonachón. Se reía de su propia suerte.

RoDRíGuEZ: ¿Vos sabés lo que pasa conmigo? Tengo yeta, eso es lo que pasa. Me eligen delegado y vienen $\operatorname{estos}^{24}$ y me refunden el sindicato. ¿Ahora qué se puede hacer? Jugar a la quiniela. Y ni eso está permitido.

MUJER: ¿Jugaste?

RODRÍGUEZ: La veta no me va a durar siempre, ¿no? Tomá la papeleta. Guardala vos. Si sale el tano te avisa. Es un tipo serio. Guardala bien.

MUJER: ¿Vas a salir?

RODRÍGUEZ: Me voy a trabajar

MUJER: ¿Esta noche?

RODRÍGUEZ: Sí.

MujER: Es todo lo que le ha dicho a su mujer la noche del sábado 9 de junio. Es una mentira inocente para irse a escuchar la pelea con sus amigos. ¿O sabe algo y se calla?

LIVRAGA: El gordo no sabía nada de lo que iba a pasar esa noche. Él y yo, los dos caímos por lo de Torres de pura casualidad.

WALSh: Me costó varios meses ubicar a Juan Carlos Torres. Por fin lo encontré refugiado en una embajada.

TORRES: Yo no tengo por qué mentirle; cualquier cosa perjudicial que usted me saque, diré que es falsa, que a usted ni lo conozco. Por mí, puede publicar mi nombre verdadero.

${ }^{23}$ Tachado a mano: "Rodríguez - Pienso en mis hijos. Y en las gallinas. Pero no compré maíz. Volvió a subir. Dales las sobras del almuerzo. M[ujer]: En casa de pobre no hay sobras”. Según anotaciones manuales que se encuentran al dorso, el pasaje suprimido se reemplaza por el siguiente texto, que amplía la conversación entre Rodríguez y su mujer:

"Rodríguez: Vos te creés que yo no pienso, ¿eh? Que no tengo nada en el mate. Pero yo pienso. Mirá cómo pienso./ Mujer: Ya que estás, ¿̨por qué no pensás en darle de comer a las gallinas?/ Rodríguez: Pensé. Pero se acabó el maíz. ¿Querés que vaya a comprar? Aflojá la guita./ Mujer: ¡Ta bien! Uno se ofrece por las pobres gallinas, uno se preocupa por las gallinas. Pero está bien, no voy. Pero vos no pensás en las pobres gallinas. Después las criticás porque no ponen. Deberían hacerte una huelga las gallinas./ Mujer: Dales las sobras de la cena./ Rodríguez: ¿Qué sobras? En casa de pobres no hay sobras, che./ Mujer: Pero tiene que haber maíz. Mirá que sos vivo./ Rodríguez: Soy vivo. No te diste cuenta. Me sobra la plata, el maíz, el alpiste, lo que quieras. (Se ríe). La pucha que soy vivo".

${ }^{24}$ Añadido a mano: "milicos". 
WALSH: Entiendo. Veamos los hechos. Usted alquilaba el departamento del fondo.

TORRES: Sí, la alquilaba a don Horacio Di Chiano que vivía con la familia, en la frente sobre la calle Yrigoyen. Al pobre don Horario también se lo llevaron.

WALSH: Había una reunión en su casa.

TORRES: No, no lo que usted piensa. Mire, a esos muchachos no tenían por qué fusilarlos. A mí, vaya y pase, porque yo "estaba”, y en mi casa encontraron documentación. Nada más que papeles, no armas, como dijeron después. Pero yo me escapé. Y Gavino también se escapó.

WALSH: ¿No había hablado esa noche de la revolución de Valle en su casa?

TORRES: Ni remotamente, a los que en realidad "estábamos", que éramos Gavino y yo, nos bastaba una mirada pera entendernos. Pero ni él ni yo sabíamos si íbamos a actuar ni dónde. Esperábamos un contacto que no se produjo. La desgracia fue que también cayeron otros muchachos del barrio que vieron la reunión en la casa y entraron a escuchar la pelea, a jugar a las cartas como de costumbre. En mi casa entraba cualquiera, aun sin conocerme. Hasta dos “tiras” llegaron esa noche y nadie se dio cuenta. La verdad es que al mismo Livraga, ese que nombran los diarios yo no lo conocía ni recuerdo haberlo visto.

WALSH: ¿Cuántos se reunieron esa noche?

TORRES: No sé, como doce o catorce personas.

WALSH: De todos modos, si usted “sabía”, era una imprudencia tener gente allí reunida.

TORRES: Mire, no les dijimos nada, porque la realidad es que, hasta ese momento, no había nada. Mientras no tuviéramos noticias concretas era una noche como cualquiera. Yo no podía ponerlos sobre aviso, decirles que se fueran porque iba a despertar sospechas. Y yo no acostumbro a hablar más de lo necesario.

WALSH: Carlitos Lizaso tenía veintiún años. Era un muchacho alto, delgado de carácter retraído. Trabajaba en la oficina de su padre, Don Pedro Lizaso, martillero. La noche del 9 de junio se despidió temprano de su novia y se fue a escuchar la pelea. Ella le dijo: “¿por qué te vas tan temprano?". Y él le habrá contestado.

LIZASO: Quedé con los muchachos para escuchar la pelea...

MUJER: La podemos escuchar en casa.

LIZASO: A vos no te gusta. 
MuJER: Por favor... Cuidate.

LIZASO: ¿Por qué me decís eso?

MuJER: No, por nada. Hace mucho frío esta noche.

LIZASO: No te preocupes, Chau, hasta mañana.

MuJER: Hasta mañana.

WALSH: ¿Sabía algo de la revolución que estallaba en ese ${ }^{25}$ momento? Es difícil contestar con certeza. El, ya no podrá comparecer como testigo.

MujER: Esa noche, después que él se marchó encontré un papel con su letra que decía: si todo sale bien esta noche... ${ }^{26}$

WALSH: Hubo un hombre por lo menos que pareció presentir la tragedia. Ese hombre que dos meses más tarde se volcará al terrorismo y se hará llamar "Marcelo" y será ferozmente torturado representa un curioso papel en los acontecimientos. Era amigo de la familia Lizaso y esa noche fue tres veces a casa de Torres para llevarse a Carlitos. Pero fue inútil.

MARCELO: Carlitos era como un hijo para mí. Yo sabía lo que estaba ocurriendo allí esa noche y traté de sacarlo de allí. Conocía a Torres y a Gavino, sabía que ellos esperaban un contacto para actuar cuando estallara la revolución.

WALSH: ¿Y usted cómo sabe que Lizaso no esperaba lo mismo?

MARCELO: Era un pibe. No creo que supiera nada. Lo encontré charlando, despreocupado. Vamos, le dije. Tu viejo te está esperando.

LIZASO: Andá vos. Yo voy después.

MARCELO: Te espero. Vamos juntos.

LIZASO: Te digo que no sé a qué hora voy a ir. Capaz que me quedo.

MARCELO: Dale pibe, Tu viejo me...

LIZASO: ¡No embromes con mi viejo! Me parece que ya soy mayor de edad y sé lo que...

MARCELO: ¿Sabés lo que hacés?

LIZASO: ¿Qué te pasa?

25 Añadido a mano: “mismo”.

${ }^{26}$ Llamada “5” sobre sonido en off, correspondiente a "Preludio?”. Al lado, anotación con flecha: “Bach”. 
MARCELO: Tengo que hablar contigo. Vamos a la calle.

LIZASO: Dale viejo... No jodas.

MARCELO: Era difícil hablar delante de los otros. Y no pudo hacerlo salir. Pero creo, me consta, que él no estaba en la cosa. A lo sumo olfateaba algo. Y no se lo quería perder. Más tarde volví para hablar con Torres. No me parecía correcta su actitud. Le pregunté: ¿sabe algo toda esta gente?

TORRES: No, la mayoría no sabe nada.

MARCELO: ¿Y qué hacen aquí?

TORRES: Qué sé yo... van a escuchar la pelea.

MARCELO: Pero usted, ¿por qué los tiene aquí?

TORRES: ¿Quiere que los eche? ¿Qué quiere que les diga? ¿Que va a haber una revolución? ¿Que se vayan a casita y se metan en la cama?

MARCELO: Si no confía en ellos no los utilice.

TORRES: ¿Utilizarlos para qué?

MARCELO: Para cubrirse. ¿Si cae la policía aquí no pasa nada verdad? Todo el mundo escuchando la pelea. Jugando a las cartas.

TORRES: ¿Y qué? Si no tienen nada que ver, no les va a pasar nada. Si me allanan el que se jode soy yo. A ellos no les va a pasar nada.

MARCELO: Está bien, Haga lo que quiera. Pero a ese muchacho no me lo lleva a ninguna parte ${ }^{27}$. Además esa noche ya no va a haber nada.

WALSH: Parece claro que Carlitos Lizaso sabía algo de la revolución de Juan José Valle y sabía por qué se quedaba allí.

Voz EN OFF: Transmite Radio del Estado. Tiempo nublado y frío en la ciudad de Buenos Aires. Temperatura reinante en la capital de la provincia cuatro grados bajo cero.

-Che, pongan Radio Splendid a ver si nos perdemos la pelea ${ }^{28}$.

${ }^{27}$ Añadido a mano: "T: Quédese tranquilo que no lo llevo a ninguna parte".

${ }^{28}$ Sexta llamada sobre sonido en off, “6”. Corresponde: “Locutor (E del tiempo)”. 
WaLSH: A Miguel Ángel Guinta, lo llamaban Don Lito en el barrio. Aunque no había cumplido los 30 años, era un hombre sólido, maduro, formal ${ }^{29}$.

GIUNTA: Esa noche, a eso de las 9, yo volvía del trabajo.

(Música de Haydn) $^{30}$

WALSH: ¿En qué trabajaba usted?

GiUNTA: En una zapatería. Como vendedor. Bueno, esa noche no encontré a Don Horacio.

WALSH: ¿Quién es Don Horacio?

GIUNTA: Don Horacio Di Chiano. Era un vecino, un hombre mayor ${ }^{31}$. Era el dueño de la finca de la calle Yrigoyen, vivía en el frente y alquilaba a un tal Torres el departamento del fondo.

WALSH: Hacía diecisiete años que Horacio Di Chiano trabajaba en la Ítalo como electricista. Esperaba jubilarse y trabajar unos años por cuenta propia antes de retirarse definitivamente.

DOn Horacio: Los jóvenes de hoy no saben lo que es el ahorro. Yo, juntando peso sobre peso, me compré una casita. Para dejarle algo a mi hija. Pero la vida me hizo una jugarreta. Aquel sábado 9 de junio me encontré con mi vecino Giunta en la esquina de mi casa.

GiuNTA: Adiós, don Horacio. Fría la noche, ¿eh?

Don Horacio: ¡Me lo va a decir a mí! Tuve que ir hasta Palermo por un reclamo de luz.

GIUNTA: ¿Y qué me dice de la pelea de esta noche?

DON HORACIO: El chileno es bravo.

GiUNTA: ¿Usted cree? Pero Lausse es un campeón. Le gana por nocaut el segundo round.

DON Horacio: ¿Por qué no se viene a mi casa a escuchar la pelea después de la cena?

GIUNTA: No le prometo nada, pero en una de esas....

DON HORACıO: Traiga a su señora ${ }^{32}$.

\footnotetext{
${ }^{29}$ Séptima llamada de sonido en off, "7". Corresponde: "Pelea (griterío - campana)".

${ }^{30}$ Tachado a mano.

${ }^{31}$ Añadido a mano: "de unos 50".

32 Anotación al margen con flecha: "Pelea”.
} 
GIUNTA: Al final fui solo. Mi señora no se sentía bien. $\mathrm{La}^{33}$ pelea duró menos de diez minutos. En el tercer round el campeón Lausse derribó al chileno por toda la cuenta. Don Horacio me sirvió una copita de ginebra. La señora Pilar se había acostado. Hacía frío.

MUJER: Ella dijo: viejo, llename una bolsa de agua caliente.

GIUNTA: En eso estaba don Horacio, cuando entró de golpe la policía.

FERNÁNDEZ SuÁrEZ: ¿Dónde está Tanco?

WALSH: Don Horacio solo atinó a levantar los brazos sin soltar todavía la bolsa de agua caliente. El jefe del grupo lo aparta de un empellón y se encara con Giunta. Giunta está simplemente petrificado. Ha permanecido en su silla con la boca abierta sin atinar a moverse.

El jefe se acerca a él y le apoya la pistola en la garganta.

FERNÁNDEZ SuÁrEZ: ¡No te hagas el piola! ¡Levantálas manos! ¿Dónde está Tanco?

GIUNTA: Yo no entendía nada. El que mandaba -después me enteré que era el propio jefe de policía- era una persona gruesa, quiero decir fuerte, que vestía uniforme del ejército. Me puso una pistola 45 en la garganta y me gritaba. Me dio un golpe con la izquierda que casi me voltea de la silla.

FERNÁNDEZ SUÁREZ: (Le da un empellón a don Horacio). A este y al viejo sáquenlo y llévenlos al auto.

MUJER: ¿Qué pasa? Horacio...

FERNÁNDEZ SUÁREZ: Hay que registrar todo. Quédese aquí, señora. Después, no vaya a decir que le falta algo...

MuJER: ¿Pero por qué lo llevan?

FERNÁNDEZ SUÁREZ: ¡Paren esa radio!

WALSH: Al mismo tiempo la policía irrumpía en el apartamento del fondo. Pero mientras el jefe de policía revisaba cuidadosamente la ropa interior del matrimonio Di Chiano, el inquilino del fondo, Torres -que "estaba" como él dice- ya había tenido tiempo de huir.

TORRES: Dio la casualidad de que al terminar la pelea, ese muchacho Carlitos, me pidió para hablar por teléfono y salimos al pasillo que comunica con el patrio del fondo de Di Chiano. Justo en ese momento oímos las voces, el ruido de las camionetas policiales. Yo no vacilé. Salté la tapia ${ }^{34}$, que

\footnotetext{
${ }^{33}$ Desde aquí y hasta “... por toda la cuenta”, tachado a mano.

${ }^{34}$ Añadido a mano: “del patio”.
} 
era muy alta, salté otra cerca, me trepé a una azotea, de ahí salté a otra. Me lastimé las manos, no sé cómo tenía una herida cortante en el cuello, pero lo cierto es que al final me escapé.

WALSH: ¿Y Carlitos Lizaso?

TORRES: No sé. Él no estaba comprometido en nada. Se habrá dejado detener.

Livraga: A Lizaso lo detuvieron cuando quiso saltar la tapia. Se derrumbó bajo su peso y ahí lo rodearon. A mí, uno me encajó el caño de la pistola en el estómago.

Policía: ¿Así que vos ibas a hacer la revolución? ¿Con esa facha?

FERNÁNDEZ SuÁREZ: ¿Con que este es Gavino? ¡Hable! ¿Dónde está Tanco? Decime dónde lo tenés. ¿Dónde está el general Tanco? ¡Pronto! ¡Hablá enseguida porque te mato! Mirá, no me cuesta nada $^{35}$.

WALSH $^{36}$ : El cañón de la pistola tabletea entre los dientes de Gavino. Del labio partido le brota un hilo de sangre. Tiene los ojos vidriados de miedo. Pero no le dice dónde está Tanco. O es un héroe, o realmente no tiene la menor idea sobre el paradero del general rebelde.

LIVRAGA: Le mostró la cédula. El que no me apuntaba la miró y me encajó una patada: “camina, novato”. Mi nombre no les decía nada, pero daba lo mismo. No sé si había alguno comprometido. La mayoría no entendía que pasaba ${ }^{3738}$.

WALSH: Nicolás Carranza seguro que entendía. Era peronista, Nicolás Carranza. Y estaba prófugo. Había sido ferroviario. Tenía seis hijos, la menor de cuarenta días. La mayor, de once años, había estado presa. Un día de enero de 1956 la sacaron de casa unos parientes, la llevaron sola a una comisaría y la interrogaron durante cuatro horas. ¿Llevaba panfletos, su padre? ¿Era peronista, su padre? ¿Era un delincuente, su padre?

CARRANZA: A mí, que me hagan cualquier cosa. Pero a una criatura...

MuJER: Entregate, Nicolás. Si te entregás, a lo mejor no te pegan. Y de la cárcel se sale.

Carranza: No he robado. No he matado. No soy un delincuente.

35 Añadido a mano: "Ya vas a hablar. ¡Llévenselos para el auto!”.

${ }^{36}$ Tachado a mano desde aquí y hasta "No sé si había alguno comprendido".

${ }^{37}$ Añadido a mano: "Los hicieron subir a un colectivo".

${ }^{38}$ Llamada "8" sobre sonido en off, que corresponde a "Ravel". 
WaLSH: Toda una escalera de pibes tenía don Carranza ${ }^{39}$. Los veía de vez en cuándo. De vez en cuando aparecía furtivamente y el barrio lo saludaba

-“Chau, don Carranza”.

WALSH: Pero él se levantaba hasta los ojos la solapa del sobretodo y seguía de largo. En su casa podía respirar un rato. Jugaba con los pibes imitando el ruido de los trenes que manejaban hombres como él. Gente de esa barriada ferroviaria.

CARRANZA: Ahí viene el ferrocarril del norte. (Imita silbato). ¡Bajen las barreras! (Silbato) Vienen con quince vagones.

MujER: Nicolás, ¿qué vamos a hacer si nos quitan la casa ahora que estamos cesantes? ¿Dónde vamos a ir?

CARRANZA: Nos vamos con el ferrocarril del Norte. (Silbato). Mi ferrocarril. (Imita el ruido).

MuJER: No es tuyo. Es de la compañía. Y esta casa también. ¿Qué hacemos si nos echan? Y si te agarran por ahí....

CARRANZA: Si me agarran, me agarran.

MujER: Son capaces de pegarte hasta dejarte idiota. Entregate, Nicolás. Si te entregás a lo mejor no te pegan.

Carranza: Las nueve. Tengo que irme.

RADIO $^{40}$ : Transmite Radio Splendid. (Gardel). Preliminares de la pelea del fondo.

MUJER: ¿Adónde vas?

CARRANZA: Tengo que hacer. A lo mejor vuelvo mañana.

MUJER: ¿¿No dormís acá?

CARRANZA: No. Esta noche no duermo acá. Hasta mañana.

WALSH: No hubo otra mañana. Nicolás Carranza había puesto en esa noche toda su esperanza. Si se daba un vuelco, si las cosas salían bien...

EN OFF: Marcha final de Radio del Estado ${ }^{41}$.

\footnotetext{
${ }^{39}$ Anotación al margen, con flecha: "Disolver música".

40 Tachado a mano hasta "del fondo".

${ }^{41}$ Llamada "9" sobre sonido en off, correspondiente a "Marcha final Radio del E ". 
WALSH: En el despacho del jefe de la Unidad Regional San Martín, inspector Rodolfo Rodríguez Moreno, está encendida la radio. A la hora 24 del sábado 9 de junio, Radio del Estado ha cerrado como siempre su transmisión con su marcha característica.

MUJER: Ni una palabra sobre la sublevación de Valle ni sobre la ley marcial.

WALSH: Según el libro de locutores de Radio del Estado, la voz Oficial de la Nación, transmite a las 22 y 31 música de Bach, a las 22 y 59, Ravel; a las 23.30 Stravinsky.

MUJER: A las 24 cierra normalmente su transmisión ${ }^{42}$.

WALSH: Pero a las 0.11 del domingo 10 Radio del Estado conecta sorpresivamente con la cadena (música ligera $)^{43}$ oficial y por espacio de veintiún minutos propala una selección de música ligera. Es el primer indicio oficial de que algo serio ocurre en el país.

MUJER $^{44}$ : Alas 0.32 en punto, se vuelve a oír la voz del locutor oficial.

EN OFF: Se va a dar lectura a un comunicado de la Secretaría de Prensa de la República ${ }^{45}$.

WALSH: Es la primera noticia que tiene el país del decreto de la ley marcial ${ }^{46}$.

MuJER: Entretanto, los detenidos de la casa de la calle Yrigoyen ya han llegado a la Unidad Regional San Martín. Los introducen en una oficina y les dicen que esperen.

WALSH: A la una y 30 se difunde el comunicado $\mathrm{N}^{\circ} 1$ de la Vicepresidencia de la República.

EN OFF" : "En nombre del Sr. Presidente Provisional se comunica al pueblo que a las 23 del día sábado, se produjeron levantamientos militares en algunas unidades de la provincia de Buenos Aires. Se ha decretado el imperio de la Ley marcial en toda la República. Se recomienda a la población tener calma y confianza en la fuerza y la consolidación de la Revolución Libertadora”. Firmado Isaac F. Rojas, Contraalmirante, Vicepresidente Provisional.

-Decretaron la ley marcial ${ }^{48}$.

\footnotetext{
42 Anotación al margen: "Fin marcha".

${ }^{43}$ Llamada "10” sobre sonido en off, que corresponde a "Música ligera”.

44 Tachado y corregido a mano: "W[alsh]".

45 Llamada " 11 " sobre sonido en off, correspondiente a "Locutor".

46 Anotación al margen: "sigue pág. 10".

47 Llamada "12" sobre sonido en off. Corresponde a "Locutor".

${ }^{48}$ Anotación al margen: "Viene de pág. 9". En el diálogo entre detenidos que aquí comienza, el texto mecanografiado no especifica en todos los casos los personajes que intervienen. Algunos de ellos, los que hemos encorchetado, se pueden establecer según aclaraciones realizadas a mano ("R[odríguez]” y "L[ivraga]”).
} 
-¿A qué hora? ¿A qué hora?

-Menos mal. A nosotros nos agarraron antes ${ }^{49}$.

[RODRíGUEZ]: Che, el grandote era el jefe de policía; Fernández Suárez en persona.

-¿El jefe de policía?

[LIVRAGA]: ¿Estás metido en algo, vos?

[RodRíGuEZ]: Sé tanto como vos, gordo ${ }^{50}$. (Alpúblico). Vino un policía y nos dijo:

Policía: Muchachos, ¿ustedes son detenidos políticos?

[RODRÍGUEZ]: ¿¿Nosotros?

[RODRíGuEZ]: ¡Yo qué sé! Yo fui a escuchar la pelea.

PoLiCía: Pónganse contentos. Estalló la revolución y ya no tenemos comunicación con La Plata.

-Revoluzione! Ma corpo de Cristo, que revoluzione!?

[RODRíGUEZ]: Este gringo es sereno de la fábrica. Lo agarraron en la calle y marchó con nosotros.

LIVRAGa: ¡Qué relajo! ¿Pero por qué el jefe de policía en persona? ${ }^{51}$

Don Horacio: A mí me interrogaron en la policía ${ }^{52}$. No me golpearon. Un oficial me hizo unas preguntas.

POLICÍA: ¿Nombre?

Don Horacio: Horacio Di Chiano.

POLICía: ¿Qué hacía usted en esa casa?

${ }^{49}$ Añadido a mano: "W: A la 1 y 30 se difunde".

50 Tachado y corregido a mano: "pibe".

${ }^{51}$ Anotación al margen: “(1)”. Es una llamada al siguiente texto añadido que se encuentra al dorso:

"Rodríguez: ¿Alguien tiene un pucho? / Walsh; Un oficial de policía le dijo al otro./ Policía: Si la cosa se da vuelta los soltamos enseguida./ Carranza: ¿Tiene fuego? / Policía: Hay una radio rebelde./ Lizaso: ¿Oyeron? Hay una radio rebelde./ Rodríguez: ¿Quién dijo?/ Carranza: Uno de los milicos./ Don Horacio: A mí me interrogaron en la Regional San Martín.../ (...)/ Rodríguez: ¡Pucha que hace frio!/ Livraga: Che, a ver si todavía nos matan/ (Pausa)/ Livraga: ¿Pero nos van a tener aquí toda la noche?/ Rodríguez: No sé. No sé nada. Tranquilizate flaco./ Carranza: A nosotros no nos toca la Ley marcial./ Lizaso: Seguro. No hicimos nada./ Livraga: No se puede hablar por teléfono./ Rodríguez: ¡Che! ¡Déjenme dormir!/ Sereno: Revoluzione. Ma qué revoluzione./ Rodríguez: ¡Callate, gringo!/ Policía: Silencio, ustedes están incomunicados. No se puede hablar./ Rodríguez: Pasa que nos estamos cagando de frío./ Me dieron un recibo por mis cosas. Me parece que no nos piensan largar./ Policía: Silencio, no se puede hablar".

52 Tachado y corregido a mano: "reg. San Martín". 
Don Horacio: ¿Qué iba a hacer?... Es mi casa.

POLICÍA: ¿Qué hacía?

DON Horacio: Estaba con mi familia, escuchando la radio.

Policía: ¿Nada más?

DON HORACIO: Nada más.

EN OFF 53 : "Todo oficial de las Fuerzas Armadas y cumpliendo actos de servicio, podrá ordenar juicios sumarísmos con atribuciones, para aplicar o no, pena de muerte por fusilamiento, a todo perturbador de la tranquilidad pública”.

- ¿Por qué nos habrán traído?

- ¿Yo qué sé? Por jugar a las cartas.

- Mirales la cara. Pasa algo feo. A ver si todavía nos matan.

LIVRAGA: De pronto notamos un cambio de actitud en los guardias.

Policía: ¡Silencio! Ustedes están incomunicados. No pueden hablar.

- La mujer de Carranza le había dicho: "Entregate, Nicolás”. Bueno, ahora ya estaba entregado. Ya no tenía que seguir huyendo, Sabía que estaba sonado. Los demás podía ser que salieran... pero él... Apenas pidieran sus antecedentes...

POLICÍA: ¿Nombre?

CARRANZA: Nicolás Carranza.

POLICÍA: ¿Ocupación?

CARRANZA: Trabajaba en el Ferrocarril del Norte ${ }^{54}$.

\section{MADRUGADA DEL 10 DE JUNIO}

MUJER ${ }^{55}$ : A la mayoría se les tomó declaración. Todo ocurrió en un par de horas.

${ }^{53}$ Llamada "13" sobre sonido en off, correspondiente a "Locutor".

${ }^{54}$ Llamada "13" sobre sonido en off, correspondiente a "Bach".

55 Anotación al margen: "Bach". 
WALSH: No fue fácil obtener el testimonio de los sobrevivientes. En primer término obtuvimos la declaración de Livraga.

LivRaGa: Nos llevaron primero a la Unidad Regional San Martín. De allí, nos sacaron y nos hicieron subir a un colectivo. Había un frío bárbaro. Me acuerdo que Giunta sólo llevaba una campera. Uno dijo: "Yo creo que nos matan, don Lito". A mí me hizo gracia. Nos habían dicho: "Quédense tranquilos. Los trasladamos a La Plata”. A cierta altura en el cruce de la ruta 8 paramos. Me di cuenta de que no íbamos hacia La Plata, pero no le di importancia. Yo iba tan confiado que, cuando paramos allí en el cruce y el chofer se bajó porque se sintió descompuesto, me ofrecí a manejar. "Si quieren manejo yo. Yo soy colectivero". Ahí noté que los de la camioneta estaban nerviosos. Pero, con la policía nunca se sabe... Bueno, al final volvimos a parar. Era un lugar medio descampado, en las afueras de José León Suárez. Nos hicieron bajar en un baldío. Había eucaliptos en la calle. Al fondo del baldío estaban los basurales. Entonces, la camioneta dio vuelta por una calle lateral y nos alumbró las espaldas con los faros. Nos dijeron: “Caminen”. Alguien preguntó: “¿Qué nos van a hacer?” Oí que decían: "No tengan miedo. No les vamos a hacer nada”. Al lado mío alguien dijo: "Dispará, Carranza, yo creo que nos matan”. Yo iba en la punta. Pensé: "el traje oscuro, si me abro hacia la izquierda, quedo en la oscuridad". Si corría era peor, nos estaban apuntando. Pero fue un segundo, un paso a la izquierda y ya no sentí los faros. A unos metros había una zanja, pero a mis espaldas, oí el cerrojo de los máuseres y no pude correr. Me tiré al suelo y quedé boca arriba, no sé por qué. No me animaba a moverme. Vi cómo lo mataron a pocos pasos de mí, al pobre Carranza.

MuJER: Entregate, Nicolás. Si te entregás a lo mejor no te pegan, Y de la cárcel se sale.

-"No he robado. No he matado. No soy un delincuente".

LivRAGa: En vez de correr, como hizo el que iba con él, Carranza se dio vuelta de cara al pelotón y se puso de rodillas. "Por mis hijos"... No sé, quería decir algo, pero le vino un vómito. Ya habían empezado a tirar. Se oían gritos. Entonces vinieron dos. Uno le apoyó el fusil en la nuca a Carranza que seguía de rodillas y le disparó, después le acribillaron todo el cuerpo. Y a cada tiro saltaba como un muñeco de goma. De pronto, noté que los faros empezaban a virar hacia la izquierda, hacia donde estaba yo. Cerré los ojos. Un gritó: “¡Dale a ése que todavía respira!”. Oí tres explosiones. Un dolor como un cuchillo me traspasó la cara y se me llenó la boca de sangre. No sé cuánto tiempo pasó. Pero en ningún momento perdí el conocimiento. Me dolía la cara, no tragaba sangre, me ahogaba, pero veía y oía. El pibe alto, flaco - que llamaban Carlitos- fue el último que fusilaron. A ese lo agarraron entre varios. Lo arrastraron hasta el medio del baldío. Primero se resistía como un loco. Y cuando lo soltaron se quedó quieto, iluminado por los faros. Ellos formaron el pelotón y le tiraron. Como en el cine. 
VOZ DE MUJER: Si todo sale bien esta noche...

WALSH: Pero todo salió mal ${ }^{56}$.

Livraga: Mi amigo Rodríguez se había tirado a pocos pasos de donde estaba yo. Pensé que estaba herido, pero de repente se levantó bajo la luz de los faros y quiso correr. Le tiraron de lejos, y quedó revolcándose. Mal herido. Pobre gordo, debía estar muy mal, porque pedía que lo mataran. Al final se acordaron de darle el tiro de gracia, y se quedó quietito. Uno lo vuelve a contar y le parece increíble. Pero fue así. A lo último ellos se fueron y yo traté de incorporarme. Me apoyé en el brazo derecho y descubrí que tenía otro balazo. Pero igual me levanté. Me metí en el basural. Lo había visto correr a Giunta hacia ese lado. Quería encontrarlo. Pero no lo encontré hasta mucho más tarde en la cárcel de Olmos. Medio mareado salí a la calle. Vi el letrero de la estación ferroviaria José León Suárez. Y alguien me habló. Como en una pesadilla le vi el uniforme. Era un oficial de policía. Pero no me importó. Me alegré de encontrarme con alguien. Yo debía parecer salido de una película de terror, con la cara desecha. Chorreando sangre. El tipo me sostuvo porque yo me caía y me llevó hasta un jeep.

-Decime la verdad, pibe. ¿Qué pasó?

[LivraGa]: “Nos fusilaron”. Me parecía increíble oír mi propia voz. "Hijos de puta. Nos balearon”. Escupir mi voz junto con mi rabia y mi sangre.

EN OFF: Que nadie se equivoque. La Revolución Libertadora cumplirá inexorablemente sus fines ${ }^{57}$.

LIVRAGA: El oficial me llevó derecho al Policlínico San Martín. Me hicieron las primeras curas, y les conté todo. Una enfermera le avisó a mi viejo. Otra, guardó el recibo que me habían dado por mis cosas en la Unidad Regional San Martín. Mi madre estaba recién operada y no le dijeron nada. Pero mi viejo llegó casi enseguida con mi cuñado y dos primas. Ellos firmaron en el libro de entrada que me habían visitado y que mi estado no era grave. Sabía que si yo era el único testigo iban a tratar de hacerme desaparecer. Pero yo les dije: "Hay otros, hay otros que también se escaparon”. Esa noche me pusieron una custodia policial. Las enfermeras me contaron que el cabo había dicho: "a este se lo van a llevar de nuevo. No se lo digan, pobre”. Pero ellas se jugaron por mí. El cabo pidió mis ropas. Le dijeron que no las tenían. Entonces, el tipo exigió el recibo. En mis ropas tenía que estar el recibo, o sea la prueba de que me habían detenido el 9 de junio en la Unidad Regional San Martín. Ellas no sabían nada. Pero esa noche, mi viejo encontró el papelito, misteriosamente, en el bolsillo de su sobretodo.

56 Esta intervención y la anterior se encuentran señaladas con un corchete junto al que se anota: "No".

${ }^{57}$ Intervención tachada. 
WALSH: Con ese papelito, don Pedro Livraga pudo presentarse más tarde ante el juez para reclamar a su hijo, detenido el 9 de junio y desaparecido con posterioridad.

LivRAGa: Una enfermera me dijo llorando: "Pibe, te llevan". Después me pusieron en una camilla, me metieron en un jeep y de ahí me tiraron, desnudo, en un calabozo. Pasaron no sé cuántos días. La venda que me habían puesto en el hospital se iba pudriendo, se me caía sola, a pedazos. Una noche, el comisario entró al calabozo. Traía con la punta de los dedos, una manta rota y mugrienta. Me la dejó caer encima y me dijo: "Esto no se puede pibe... Hay órdenes de arriba. Pero te la traigo de contrabando". Esa noche me dormí, sintiendo como compañía, el olor del perro que se acostaba siempre en ella.

WALSH: Juan Carlos Livraga, aquella noche, era el perro leproso de la Revolución Libertadora ${ }^{58}$.

Pero ${ }^{59}$ entre tanto, su padre ha empezado a buscarlo, la policía no sabe nada. Pedro apela a la Presidencia. Envía esa misma noche, o sea al día siguiente del fusilamiento, un telegrama a la Casa Rosada, denunciando la desaparición de su hijo. Recibe, el 12 de junio, la siguiente respuesta:

-Referente telegrama fecha 11 informo su hijo Juan Carlos fue herido durante tiroteo; escapado, posteriormente fue detenido y se encuentra alojado comisaría Moreno. Firmado. Jefe Casa Militar.

WALSH: Los familiares de Juan Carlos vuelan a la comisaría de Moreno. Y allí se repite la vieja artimaña policial. Juan Carlos -aseguran los mismos funcionarios que acaban de verlo tirado en un calabozo- no ha estado nunca allá.

Mujer: Don Pedro Livraga les muestra telegrama de la Presidencia. Pero es inútil, Juan Carlos no está allí. Ellos no lo conocen. (Música) $)^{60}$

WALSH: Es matador escuchar a Giunta, porque uno tiene la sensación de estar viendo una película que desde que se rodó aquella noche, gira y gira dentro de su cabeza, sin poder parar nunca. Están todos los detalles, las caras, los focos, el campo, los grandes ruidos, el frío y el calor, la escapada entre las latas y el olor a pólvora y el pánico y uno piensa que cuando termine va a empezar de nuevo, como es seguro que empieza dentro de su cabeza ese continuo, eterno: “¡Así me fusilaron!”.

\footnotetext{
${ }^{58}$ Llamada "15" sobre sonido en off, que corresponde a "Bach (preludio)".

${ }^{59}$ Tachado a mano desde aquí y hasta "Ellos no lo conocen" (vid. infra).

${ }^{60}$ Anotación al margen: "Preludio".
} 
GiUNTA: En el colectivo, Mario Brion que iba al lado mío, me dijo: "Che Giunta, yo creo que nos matan". Pero parecía imposible. En la unidad regional me había encontrado con el comisario Cuello. El hombre me conocía. Cuando me vio, me pegó un grito.

Policía: ¡Señor Giunta!... ¡Pero señor Giunta!... ¡Pero usted estaba en esa casa? ¿De veras estaba?

GiUnTA: Me estaba pidiendo que le dijera que no. Él sabía que yo era inocente, y le daba pecado mandarme a morir. Pero yo... ¿cómo podía imaginarme? Estaba tranquilo. No tenía por qué mentir. Le dije: sí, yo estaba.

-Está bien. Vaya.

GiUNTA: Pero en cuanto bajamos del colectivo en aquel descampado me di cuenta de lo que iba a pasar. Cuando nos gritaron: ¡Alto!, yo corrí. Un tiro me silbó junto a la oreja y me tiré cuerpo a tierra y me quedé quieto. Después volví a correr zigzagueando y me metí entre los basurales. Más tarde, me acerqué a la zona poblada. Una mujer se puso a gritar cuando me vio entrar al jardín de su casa.

MUJER: ¡Ni se atreva! ¡Ni se atreva a acercarse!

VOZ DE HOMBRE: ¿Qué pasa?

MUJER: ¡Es uno de esos! Se escapó de la policía. ¡Tirale vos! Tirale. ¡Tirale a matar!

Giunta: Pensé que todos se habían vuelto locos. En una esquina por fin, me animé a hablar con tres muchachos. Les conté toda la verdad, y les pedí unas monedas para volver a Buenos Aires. Uno me dio unos pesos. Otro un billete de diez. En la estación de ferrocarril vi que un tipo me observaba. Recién entonces, me di cuenta que estaba sudando a pesar del frío y tenía los zapatos embarrados, los pantalones rotos. Subí al tren, y el tipo atrás mío. Empecé a caminar por los vagones, el tipo me seguía casi pisándome los talones. De golpe me senté, y él también. Lo veía reflejado en el vidrio oscuro de la ventanilla, relojeándome. Solo sabía que tenía que escapar, ver un abogado, salir de aquel infierno. Cuando el tren salía de San Andrés, me decidí: esperé que agarrara velocidad... Y entonces de un salto corrí hacia la puerta, la abrí, bajé los escalones y me tiré. No me maté por milagro. Pero en realidad la pesadilla recién estaba comenzando. En San Andrés tomé un colectivo y me fui a casa de mi hermano. Esa noche, dormí en casa de mis padres y al día siguiente -el 11 de junio- fui, como si no hubiera pasado nada, a mi trabajo. Pero de tarde cuando llegué a mi casa, mi mujer me dijo que había estado la policía. Pensé: me están buscando. ¿Qué podía hacer? ¿Esconderme? ¿Vivir como un delincuente, huyendo? Decidí presentarme y aclarar las cosas. Después de todo, había habido un error. A mí, hay mucha gente que me conoce. Usted pregunte. Todo el mundo le puede decir quién soy. Hace quince años que trabajo en la misma zapatería. Desde los catorce. Y nunca me metí en nada. 
WALSH: ¿Fue usted detenido por segunda vez?

GiunTA: Sí. Me presenté y me detuvieron. Me trasladaron a la Unidad Regional San Martín, en averiguaciones. Me encerraron con llave en una especie de cocina. Conmigo, entró un guardián, que me hizo sentar en un rincón. Me apuntaba con la pistola y repetía: "Si avanzás un paso, te quemo. Si hablás, apretó el gatillo. ¡Andá, movete, así te puedo pegar un tiro!”. Y así día tras día. Los guardias se turnaban. Hablaban entre ellos: “Esta noche «sale»...” “¿Para dónde?” "Y... dos veces no se salva ninguno". Apenas me daban de comer. Tenía que dormir sobre las baldosas, en pleno junio, con unas heladas terribles. Apenas me dormía me despertaban gritando: "Cuidado que se escapa". Una vez me pasaron a un cuarto del primer piso. La ventana daba al patio. "No se le ocurra escaparse por ahí", me dijo un oficial señalando la ventana. "Porque si no se mata del golpe... En fin, piénselo. Es una opinión”. Pero yo trataba de no pensar. Porque las ideas se me enredaban. De repente sentía una risa y daba un salto. ¿Quien se podía reír, allí, de ese modo? Y era yo, Me tapaban la boca, asustado, pedía disculpas, hablaba solo. "Tranquilo, viejo. Soy yo. No hay que dejarse llevar. Tranquilo". Así, un día, y otro y otro. Me trasladaron de nuevo a la comisaría 1ra. de San Martín. Allí en ocho días no me dieron ni un plato de comida. Los presos comunes me tiraban sobras por la mirilla de la celda. Me daban de beber, pasando por el agujero, el pico de una caldera. Los guardias, parece que se habían olvidado de mí. Me dejaron solo ocho días ${ }^{61}$ pensaba: "vienen a llevarme, ahora me fusilan de nuevo". Y oía gritos, el alarido de Carlitos Lizaso, cuando lo arrastraron entre tres o cuatro... O tal vez fueran gritos de algún preso al que le estaban dando la máquina...

[WALSH]: ¿Qué más? ¿Qué sucedió después?

[GIUNTA]: El 25 de junio me trasladaron engrillado y esposado como un delincuente feroz, al penal de Olmos. Allí, me encontré con Juan Carlos Livraga. Yo no lo reconocí. Apenas lo había visto aquella noche. Pero él, me habló enseguida. Me empecé a sentir mejor, a salir poco a poco del infierno. Pudimos hablar con un abogado, y el 16 de agosto del mismo año, nos pusieron en libertad. Algunos meses después, la Policía Federal, me extendió un certificado de Buena Conducta. Se lo puedo mostrar, si quiere.

MujER: $\mathrm{A}^{62}$ último momento, Giunta se acuerda de algo que él dice que oyó decir, no está seguro, pero piensa que hay otro que se salva además de Livraga y él.

\footnotetext{
${ }^{61}$ Anotación: “(1)”. Es una llamada a un texto añadido que se encuentra al pie de página: “(1) Ni siquiera me sacaban para hacer las necesidades. Cada vez que sentía pasos”.

62 Tachado desde aquí y hasta el final de la invención de la Mujer.
} 
WALSH: La rueda sigue girando ${ }^{63}$; hay que ir por esos andurriales en busca del tercer hombre: Horacio Di Chiano. Don Horacio se ha vuelto lombriz y vive bajo tierra. Nos dice que no está, pero una nena en la calle, me para y me dice: "El señor que ustedes buscan está en su casa. Les van a decir que no está, pero está”. Le digo: “¿Y vos sabés por qué venimos?” "Sí, yo sé todo”.

-Ya les dije que no está.

-La puerta se cierra, pero poco a poco se va venciendo el temor, la desconfianza; se pronuncian palabrasganzúa, hasta que la más oxidada del manojo funciona y Don Horacio Di Chiano sube la escalera tomado de la mano de su mujer, que lo trae como un chico.

MujER: Estuvo cuatro meses oculto, antes de volver a casa. Nunca volvió a ser el de antes. A él no lo hirieron, pero usted se da cuenta... Perder el empleo, vivir así... escondiéndose...

DON HoRACIO: Yo fui el primero que hicieron bajar de la camioneta. La primera descarga no me alcanzó por milagro. Me tiré antes -a uno el miedo le devuelve la agilidad- y quedé boca abajo, ni siquiera se me habían roto los lentes. Oí varias descargas y gritos. Después un silencio y el ruido de un motor. Pensé: ahora se van. Y de pronto, un tiro. El ruido del motor y otro tiro. El tiro de gracia. ¿Se da cuenta? Estaban recorriendo cuerpo por cuerpo y rematando a los que todavía se movían. Me vinieron ganas de vomitar, cuando senti ${ }^{64}$ que me estaban alumbrando, se habían detenido y ${ }^{65}$ apuntaban. Y yo tratando de contener la arcada que me subía del estómago ${ }^{66}$. Nadie decía nada y yo ahí esperando el tiro no sé cuánto tiempo sin respirar, sentía el sudor frío que me resbalaba por la cara y pensaba: se van a dar cuenta; pero el tiro no llegaba... Hasta que volvieron a encender el motor y se alejó la luz de los faros y entonces empecé a respirar, despacio, despacito, como si estuviera aprendiendo a hacerlo por segunda vez. Vaya a saber por qué no tiraron. Me dejaron así... ¿ ¿se da cuenta? Reventado... No podía volver al empleo. Me había escapado: no podía.

$-Y$ ahora, nos estamos gastando todos los ahorros ${ }^{6768}$.

\footnotetext{
${ }^{63}$ Anotación al margen: "Bach". Junto a ella se encuentra la llamada "16" sobre sonido en off, que por supuesto corresponde a "Bach".

64 Tachado y corregido a mano: "vi”".

65 Añadido a mano: "sentí que me".

66 Añadido a mano: "Me ahogaba".

${ }^{67}$ Un añadido a mano, "M”, especifica que quien habla es la Mujer.

${ }^{68}$ Llamada " 17 " sobre sonido en $o f f$, correspondiente a "Marcha".
} 


\section{EL PROCESO}

WALSH: La primera reacción oficial frente a los fusilamientos de junio de 1956, fue el traslado de Rodríguez Moreno, el jefe de la Unidad Regional de San Martín, a Mar del Plata. Sin duda, la ejecución se había llevado a cabo $\sin ^{69}$ eficiencia. No se había tomado los nombres de los fusilados. Varios habían logrado escapar. Se habían dejado los cuerpos -muertos o agonizantes- en aquel baldío en las afueras de José León Suárez. Al día siguiente, los vecinos se congregaron en torno al macabro espectáculo.

-Eran estudiantes.

-Sí, iban a asaltar el Campo de Mayo.

MUJER: Los vecinos nos contaron que se detuvo un auto y una mujer asomó la cabeza por la ventanilla y preguntó qué pasaba.

- Esa gente... Que los han fusilado.

-Y ella dijo: Muy bien hecho. Tendrían que fusilarlos a todos.

$\mathrm{WALSH}^{70}$ : Hubo un silencio. Y de pronto un cascote de barro se aplastó contra la carrocería. Luego otro y otro. El auto se alejó perseguido por insultos y los cascotes, que desahogaban su rabia impotente.

MUJER: Recién a las diez de la mañana llegó una ambulancia y se llevó los cadáveres.

WaLSH: Disgustado por la torpeza del procedimiento el Jefe de Policía Fernández Suárez se limitó, sin embargo, a trasladar a Rodríguez Moreno a Mar del Plata. Convenía echar tierra sobre el episodio, por las mismas razones por las que se había mandado vaciar dos camiones del ejército - uno de cal y otro de alquitrán- sobre la zanja, en cuya agua estancada se pudría la sangre de los fusilados, entre hilachas de masa encefálica.

MUJER: El 12 de junio los diarios publican una lista -suministrada por el gobierno nacional- de cinco fusilados en la zona de San Martín. La noticia no indica quién los detuvo, quién ordenó matarlos ni por qué, no alude siquiera a la fuga de varios condenados.

WALSH: Durante cuatro meses no se habla más del asunto.

\footnotetext{
69 Tachado y corregido a mano: “con mucha".

${ }^{70}$ Intervención completa tachada a mano.
} 
Fernández Suárez puede dormir tranquilo, sin duda, los familiares de las víctimas se inquietan, se producen pequeños incidentes, que por supuesto, no llegan hasta el despacho del jefe de policía. Por ejemplo, la esposa de Vicente Rodríguez -el Gordo como lo llama Livraga- se presenta en la Unidad Regional San Martín, para preguntar por su marido. Al cabo de una hora la atiende un oficial.

MuJER: Me dijeron que estaba aquí, preso. ¿Qué hizo? ¿Es algo malo señor oficial?

Oficial: ¿Usted no leyó los diarios?

MUJER: ¿Los diarios?

OFICIAL: Sí, los diarios informaron.

MujER: No leí, no leo los diarios.

OFICIAL: ¿Usted es analfabeta?

WALSH: Conste aquí. Consten las ventajas que da el alfabeto para martirizar a una pobre mujer.

Oficial: Hubo muchos fusilados. Entre ellos su esposo.

WALSH: Le mostraron el cadáver de Vicente. Preguntó podía llevárselo para velarlo. Le dijeron que no.

OfICIAL: Vuelva con el cajón. Y de aquí, derecho al cementerio. Ah, y tiene que ser antes del viernes. Si no, no lo encuentra.

Mujer: Pero a comienzos de octubre de 1956, el Servicio de Informaciones Navales informa confidencialmente al Jefe de Policía Fernández Suárez que uno de sus propios hombres ha ido a denunciarlo.

WALSH $^{71}$ : El abogado Jorge Doglia -treinta y un años, radical intransigente-, acababa de ser designado Jefe de la División Judicial de la Policía.

FERNÁNDEZ SUÁREZ: Único caso en mi jefatura: que un señor de la calle pase a Inspector Mayor. Y todavía se permite acusar a la Policía.

MuJER: Hombre de sinceras convicciones libertadoras, Doglia se ha tomado en serio el lema del año 1956: Imperio del Derecho.

WALSH: Pero apenas asume su cargo, descubre que los detenidos que prestan declaración ante él, se quejan de torturas y muestran huellas de castigos. Fernández Suárez lo cita a su despacho.

71 Tachado a mano desde aquí y hasta “... lo cita a su despacho” (vid. infra). 
FERNÁNDEZ SuÁREZ: Muy bien, doctor Doglia. Tengo entendido que usted anda preocupado por algunas denuncias.

DOGLIA: Estas fotos atestiguan que los presos han sido azotados con alambres.

FERNÁNDEZ SUÁREZ: Eso no es alambre. Eso es goma.

DOGLIA: Quiere decir que usted admite los malos tratos...

FERNÁNDEZ SUÁREZ: Ve, doctor, usted, ¿cuánto hace que está en la policía?

DoGLIA: Le advierto que si no se toman medidas, presentaré la denuncia correspondiente ante el gobierno interventor de la provincia.

FERNÁNDEZ SUÁREZ: ¿Usted cree que va a jugar conmigo? ¿Con quién cree que está hablando? Usted ya denunció el hecho -yo me entero de todo-, y en lugar de venir a hablar conmigo, recurrió a un organismo ajeno a la policía, el Servicio de Informaciones Navales. Le advierto que usted es un funcionario policial y depende de sus superiores. Una cosa es tratar honestamente de corregir los males, que siempre hay cosas que funcionan mal, y otra cosa es instigar contra el instituto policial... ¿Qué significan estas fotos? Admitamos que algún subalterno golpea a un delincuente. ¿De qué lado estála justicia y el derecho? ¿Quiénes son los que defienden la ley?

DogLiA: No se trata solo de golpes -y torturas-, lo que de por sí es muy grave. Aquí se denuncia además el fusilamiento de un civil que no pasó a juez, que ni siquiera fue interrogado.

FERNÁNDEZ SUÁREZ: ¿Quién hace la denuncia?

DOGLIA: Juan Carlos Livraga, veinticuatro años, colectivero, peón de albañil.

FERNÁNDEZ SuÁreZ: ¿En qué quedamos? ¿Colectivero o peón de albañil? Todo esto es una patraña sensacionalista, tejida por algunos periodistas irresponsables.

DOGLIA: Era un civil. Fue detenido en la noche del 9 de junio y pasado por las armas unas horas más tarde, junto con otras doce o quince personas.

FERNÁNDEZ SuÁREZ: Sus datos son muy precisos, doctor. Lo felicito.

DogLia: Lo informo sobre una denuncia formal. No tengo todos los nombres, pero he visto a Juan Carlos Livraga. Presenta cicatriz de dos heridas de bala, una con orificio de entrada debajo de la mandíbula y orificio de salida en el pómulo; otra en el brazo. 
WALSH ${ }^{72}$ : Fernández Suárez a su vez acusará a Doglia de haber recurrido a un organismo ajeno a la policía para denunciar hechos ocurridos en el seno de la policía. $\mathrm{Se}^{73}$ le fragua un sumario vergonzoso, el 18 de enero de 1957 el nombre de Doglia aparecerá en los diarios, entre los de un policía borracho y otro torturador, todos igualmente destituidos por "razones éticas", de esa manera, queda a salvo el prestigio del instituto policial y el del teniente coronel Fernández Suárez, principal responsable de los hechos.

Mujer: Pero Doglia ha hablado con don Eduardo Schaposnik, representante socialista ante la Junta Consultiva de la Provincia de Buenos Aires. La Junta depende del Ministro de Gobierno y tiene un carácter meramente asesor. Pero puede discutir la conducta del Jefe de Policía.

WALSH: Lo hace en sesión secreta por iniciativa de Schaposnik. El Jefe de Policía se entera y se siente molesto. Decide, en un arranque de audacia, presentarse ante la Junta para rebatir los cargos.

FERNÁNDEZ SuÁREZ: ¡Aquí hay cargos, pero no hay pruebas! Aquí se mencionan una serie de hechos pero no se dice quién los hace, cuándo, qué pruebas puede haber... Es necesario tener hechos precisos porque si no, se puede admitir cualquier cosa... Habría que separar de su cargo al Jefe de Policía, enlodar a todo el Instituto Policial.

MuJER: Cuatro días antes, el 14 de diciembre ${ }^{74}$, Juan Carlos Livraga se presentaba por fin ante el Juez, demandando "a quien resulte responsable" por tentativa de homicidio y daños.

WALSH: Mi ${ }^{75}$ experiencia con los jueces en cuanto a periodista, no ha sido alentadora. Podría nombrar a una decena a quienes conozco por individuos facciosos, ineptos, o simplemente corrompidos. Importa señalar como ejemplo de decisión, rapidez y eficacia, la actuación que tuvo en este caso el juez Hueyo.

JuEZ: Líbrese oficio al jefe de Policía para que informe si Livraga estuvo detenido a mediados de junio y a disposición de qué juez se encontraba.

MuJER: El Jefe de Policía no se digna a responder al exhorto del juez.

WALSH $^{76}$ : El comisario de Moreno -que ha albergado a Livraga en un calabozo- responde por su parte con un despacho sibilino.

\footnotetext{
72 Tachado y corregido a mano: "F.S".

73 Añadido al margen: “D[oglia]”.

74 Añadido a mano: “de 1956”.

75 Tachado a mano desde aquí y hasta “... corrompidos”.

76 Tachado a mano desde aquí y hasta “... constancias sobre esa detención”.
} 
COMISARIO: En los libros de esta dependencia no existen constancias sobre el motivo de esa detención.

JuEZ: Informe concretamente si Juan Carlos Livraga permaneció detenido en esa dependencia y en caso afirmativo fechas de ingreso y egreso, y a disposición de qué juez se encontraba.

COMISARIO: En esta dependencia no existen constancias sobre esa detención.

JuEz: Señor Inspector Rodríguez Moreno, ¿se encontraba usted a cargo de la unidad Regional San Martín en junio de $1956 ?$

RODRíGUEZ MORENO: Efectivamente.

JuEZ: ¿Permaneció detenido en esa dependencia el denunciante Juan Carlos Livraga, el día 9 de junio de ese año?

RodríGuez Moreno: No podría precisar nombres. Recuerdo que la noche del 9 de junio ingresaron en la Unidad Regional unas doce o quince personas.

JuEZ: ¿A qué hora?

RODRÍGUEZ MORENO: Aproximadamente a medianoche, quizá un poco más tarde.

Juez: ¿Se registró el ingreso de esas personas en los libros de esa dependencia?

Rodríguez Moreno: Supongo que la Oficina de Guardia los habrá registrado.

WALSH: El Comisario Inspector supone mal. Los nombres de los detenidos no se habían registrado en el libro de entradas. Era solo una formalidad. Pero sin ella, la detención se convertía en simple secuestro.

JUEZ: ¿Cómo explica usted que los nombres no consten en el registro?

Rodríguez Moreno: Bueno, venían incomunicados y a disposición del Jefe de Policía, que los había detenido personalmente. Supongo que se entendía que venían de paso, para ser conducidos a Jefatura.

JUEZ $^{77}$ : ¿No es reglamentario inscribir a los detenidos no bien llegan a una dependencia policial?

RodríGueZ Moreno: En realidad, la Unidad Regional no tiene dependencias para alojar detenidos... Y cuando llegan algunos, es solamente de paso...

JuEz: Claro está, de paso. Aquí tengo un recibo firmado por tres oficiales, fechado el 10 de junio de 1956 en la Unidad Regional San Martín. Me fue entregado por el padre de Livraga. Aquí consta

77 Tachado a mano desde aquí y hasta “....solamente de paso”. 
que en esa dependencia judicial le fueron quitados a Livraga "un reloj marca White Star, un llavero, diez pesos y un pañuelo”. ¿Reconoce usted las firmas?

RoDríguEZ Moreno: No. Por otra parte el formulario, no es el que habitualmente se usa.

JUEZ: ¿Los detenidos fueron interrogados?

RodríGuez Moreno: Yo no los interrogué personalmente. Ordené que se les tomara declaración. Se me había informado que integraban un grupo subversivo.

JUEZ $^{78}:$ ¿Se consignaron las declaraciones por escrito?

RODRíGUEZ MORENO: No recuerdo. Es posible, pero no podría asegurarlo.

RoDríGuEz MORENO: Ante todo, debo aclarar, señor Juez, que la misión que me fue encomendada era para mí terriblemente ingrata, pues salía de todas las funciones específicas de la policía.

JUEZ: ¿Recibió usted orden de fusilar a todos los detenidos?

Rodríguez Moreno: A eso de las 4 y 30 de la madrugada, por radio policial recibí la orden terminante de proceder de inmediato al fusilamiento de todas las personas que habían sido detenidas.

JUEZ: ¿Quién impartió esa orden?

RoDríGueZ MorenO: El propio Jefe de Policía se comunicó conmigo y me indicó como plazo máximo las 6 de la mañana. Debo manifestar que a tres personas que habían sido detenidas en la calle con posterioridad al allanamiento, las puse por mi propia cuenta en libertad.

JuEZ: ¿Por qué razón?

RoDríGuEZ MORENO: Entendí que no había mérito para que estuvieran detenidas. Uno ${ }^{79}$ era un sereno italiano de unos sesenta años y otro un chofer de plaza. A los dos los conocía perfectamente y sabía que no tenían nada que ver...

JUEZ: ¿Y el tercero?

RODRÍGUEZ MORENO: No lo recuerdo en este momento.

78 Tachado a mano desde aquí y hasta “... no podría asegurarlo”.

${ }^{79}$ Añadido a mano. En el texto mecanografiado se lee "Era un sereno...”. 
JUEZ: ¿Recibió instrucciones sobre el lugar en que debía efectuarse la ejecución? ${ }^{80}$

RodríGueZ Moreno: Solo se me indicó que buscara un descampado indicado ${ }^{81}$ a ese efecto. Repito que era muy penoso para mí, pero yo tenía la plena seguridad de que en caso de desobedecer la orden, sería fusilado por desacato. Señor juez, no entiendo el motivo de esta investigación. Los fusilamientos fueron decretados bajo el imperio de la ley marcial.

JUEZ: ¿A qué hora tuvo usted conocimiento de ese decreto?

RodríGuez Moreno: Tengo entendido que el mismo fue propalado como vigente en la noche del 9 de junio entre las 22 y 30 y las 23 horas $^{82}$. Pero en la Regional San Martín nos enteramos algo más tarde. Creo recordar que tuvimos conocimiento de su puesta en vigor por boca de los propios detenidos.

JUEZ: ¿De modo que ellos se apresuraron a informarle a usted que regía la pena de muerte?

WALSH: El juez Hueyo había comprendido que el punto crucial de la investigación era precisamente la hora de la puesta en vigencia de la ley marcial.

MUJER: El Comisario Inspector también parece haberlo entendido así pues sus declaraciones son muy precisas respecto a ese detalle. En casi todos los demás aspectos se muestra dudoso y desmemoriado.

JUEZ: ¿Dirigió usted personalmente el procedimiento?

Rodríguez Moreno: En efecto. Asistió además a la ejecución el Subjefe de la Unidad Regional, pero solo como testigo y casi diría, apoyo moral en difíciles circunstancias.

\footnotetext{
${ }^{80}$ El texto mecanografiado de esta pregunta del juez y de la respuesta del comisario que le sigue se encuentra tachado a mano. Una llamada indica que el texto se reemplaza por el siguiente diálogo, anotado al dorso:

"Juez: ¿Quiere decir que usted pudo haber indultado a otros? ¿Por qué no lo hizo? (Silencio. R.M no contesta). ¿Recibió instrucciones sobre el lugar en que se debía efectuar la ejecución?

Rodríguez Moreno: Solo se me indicó que buscara un sitio adecuado. Yo me dirigí primero al Liceo Militar de San Martín, pero allí se me contestó que no se podía usar ese local. Repito que era muy penoso para mí, pero yo tenía la plena seguridad de que en caso de desobedecer la orden sería fusilado por desacato.

Juez: ¿Qué hizo usted entonces?

Rodríguez Moreno: Las autoridades del Liceo me contestaron que o tenían nada que ver con la Policía de la Provincia... Yo volví a comunicarme con la Jefatura y el propio Teniente Coronel Fernández Suárez ratificó la orden de fusilarlos. Ante las dificultades que le planteé, me dijo: « Fusílelos en cualquier baldío ». Señor juez, no entiendo el motivo de esta investigación. Los fusilamientos fueron decretados bajo el imperio de la Ley marcial”.

81 Tachado y corregido a mano: "apropiado".

${ }^{82}$ Los números “22” y “23”, que designan el horario de los fusilamientos, están escritos a mano como enmienda del texto mecanografiado, que resulta ilegible.
} 
JUEZ: ¿Se encontraba Livraga entre los fusilados? ${ }^{93}$

Rodríguez Moreno: No podría asegurarlo. Pero varios de los detenidos se dieron a la fuga cuando sospecharon con qué fines se los había llevado allí.

JUEZ: ¿Es posible que alguno de los que estuvieron frente al pelotón resultara ileso?

RODRíGuEZ MORENO: Me parece imposible.

JUEZ: ¿De modo que huyeron antes de la ejecución?

RODRíGuEZ MORENO: Es lo más lógico. De otro modo, hubieran sudo ultimados.

$\mathrm{JUEZ}^{84}$ : Livraga recibió varias heridas de bala.

RoDríGueZ Moreno: Ese caso ya fue investigado y tengo entendido que la policía -es decir el Jefe de la Casa Militar-, Capitán Manrique, informó que Livraga había sido herido en un tiroteo durante los sucesos de notoriedad.

JUEZ: ¿Se disparó el tiro de gracia contra los fusilados?

Rodríguez Moreno: Como es de práctica por razones de humanidad, di la orden de hacerlo.

JuEz ${ }^{85}$ : Livraga declara que, encontrándose herido en el Policlínico San Martín, fue detenido por segunda vez. ¿Ordenó usted esa detención?

Rodríguez Moreno: Sí, efectivamente. Supe que Livraga estaba allí internado y cuando concurrí en su busca se me informó que sus heridas permitían su traslado. Entonces dispuse que quedara alojado en la comisaría de Moreno.

WALSH: En la comisaría de Moreno, ya no pueden negar que el perro leproso de la Libertadora ha pasado por allí. El comisario De Paula también ha sido trasladado. Pero el juez lo ubica y lo cita a declarar.

JuEZ: Señor comisario, ¿se dio entrada en los libros de la comisaría al detenido Juan Carlos Livraga?

COMISARIO: No... creo que no.

JuEZ: ¿Es usual eso?

COMISARIO: No es usual, pero esto era un caso excepcional. Yo entendí que ya le habían dado entrada en la Unidad Regional San Martín.

\footnotetext{
${ }^{83}$ Esta intervención del juez y la siguiente de Rodríguez Moreno se encuentran tachadas a mano.

${ }^{84}$ Tachado a mano desde aquí y hasta “... sucesos de notoriedad”.

${ }^{85}$ Comienza aquí un extenso pasaje que se encuentra tachado a mano y finaliza en "... lo hace para admitir inesperadamente el fusilamiento de Juan Carlos Livraga" (vid. infra).
} 
JUEZ: ¿Estaba herido?

COMISARIO: Sí. El doctor Chiesa, médico de la policía, concurría diariamente a atenderlo.

JUEZ: ¿Quiere decir que estuvo bien atendido?

Comisario: Espléndidamente. Hasta se le daban alimentos que requerían ser masticados.

JUEZ: ¿No pasó frío?

COMISARIO: En mis recuerdos estaba envuelto en algo de abrigo. No podría precisar qué ropa era.

JUEZ: ¿Le tomaron declaraciones?

COMISARIO: No.

JUEZ: ¿Le hicieron sumario?

COMISARIO: No.

JUEZ: ¿Fue alguien a visitarlo, a preguntar por él?

COMISARIO: $\mathrm{No}^{86}$.

WALSH: El 22 de enero de 1957, el Jefe de Policía de Buenos Aires decide responder por primera vez a los requerimientos judiciales y lo hace para admitir inesperadamente el fusilamiento de Juan Carlos Livraga ${ }^{87}$.

FERNÁNDEZ SuÁREZ: Juan Carlos Livraga fue condenado a la pena de muerte por Decreto 10364 del Poder Ejecutivo Nacional de fecha 9 de junio de 1956.

WALSH: Esta declaración firmada por el Jefe de Policía incurre en dos errores: primero, el citado decreto es de fecha 10 de junio. Segundo, el texto del decreto impone la pena de muerte al coronel (R.) Alcíbades Eduardo Cortínez, coronel (R.) Ricardo Salomón Ibazeta, y sigue una lista de ocho militares. Pero no figuran allí los nombres de Livraga ni de sus compañeros de ejecución.

JuEz: Hágase saber al señor Jefe de Policía tal constancia solicitándole que, en caso de existir tal decreto, se sirva informar su número exacto.

WaLSH: Fernández Suárez, claro está, no responde. Hay testigos de que el único decreto y juicio sumarísmo consistía en una orden verbal del Jefe de Policía.

MujER: Jorge Dillon, Teniente de Fragata, se presenta espontáneamente a declarar ante el juez Hueyo.

${ }^{86}$ Anotación al margen, con flecha: “(1)”.

${ }^{87}$ Añadido a mano: "El juez Hueyo no descansa...". 
JoRge Dillon: Considero mi deber declarar que en la madrugada del 10 de junio último aproximadamente a las 0.45 me encontraba en mi domicilio, que está ubicado frente al departamento de Policía, y al escuchar el tiroteo con que empezó el asalto, me incorporé a la defensa de dicho Departamento. Cuando ya se había sofocado el movimiento, es decir por lo menos el ataque a la Jefatura y siendo pasadas las 4 de la madrigada, llegó el Jefe de Policía junto con un grupo de cadetes y demás personal. Los que habíamos defendido el edificio, descendimos la escalinata donde ocurrió el encuentro con los recién llegados, intercambiándose impresiones y relatos, sobre los hechos ocurridos. En esa oportunidad, el que habla, oye decir al señor Jefe de Policía, Teniente Coronel Desiderio Fernández Suárez, textualmente las siguientes palabras: “Transmita la orden a la Unidad Regional de San Martín, para que se fusile de inmediato a ese grupo de personas que yo he detenido".

FERNÁNDEZ SUÁREZ: Con respecto a este señor Livraga quiero hacer presente que en la noche del 9 de junio recibí la orden de allanar una casa donde se encontraba el general Tanco con los jefes del grupo que iban a atacar la escuela de Mecánica.

WALSH: ¿Hay un testigo, alguna prueba, alguien que haya visto al general Tanco en la finca de la calle Yrigoyen?

MuJER: Fernández Suárez acusa, juzga y condena, pero no aporta ninguna prueba.

FERNÁNDEZ SuÁREZ: A las 23 horas allané en persona esa finca. Me atrasé media hora; si lo hubiera hecho un poco antes lo hubiera tomado preso al general Tanco.

WALSH: A las 23 horas del 9 de junio. Él lo declara. Y conste por escrito. Según el libro de locutores de Radio del Estado la ley marcial se hizo pública a las 0.32 del 10 de junio. O sea que Livraga, Giunta y los demás fusilados de la calle Yrigoyen, no pudieron violarla porque a esa hora ya estaban presos.

MuJER: El propio Fernández Suárez se encarga de corroborarlo.

FERNÁNDEZ SuÁREZ: Esa madrugada el Poder Ejecutivo ordenó el fusilamiento de esa gente, que estaba por participar en estos actos o había asumido alguna actitud revolucionaria.

WALSH: "Está por participar”. Quiere decir que aún no había participado.

MUJER: "O había asumido alguna actitud revolucionaria".

JUEZ: ¿Quién juzgó lo que usted llama “actitud revolucionaria”?

FERNÁNDEZ SuÁREZ: El Poder Ejecutivo. 
WALSH: Estamos en un círculo vicioso, un círculo infernal.

MUJER: A las 24 horas del 9 de junio de 1956, no rige la Ley marcial, en ningún punto de la República.

WALSH: Pero ya ha sido aplicada. En virtud de esa Ley, se ha detenido a catorce personas, a quienes se condenará a muerte unas horas después, en virtud de una ley que no regía en el momento de su detención. A esos hombres, no se les instruyó proceso; no se averiguó quiénes eran; no se les dictó sentencia, y se los masacró en un descampado.

FERNÁNDEZ SUÁREZ: Frente al escándalo periodístico que, con fines muy claros, se ha desatado en torno a esta cuestión, conviene subrayar que la responsabilidad de las autoridades o de los encargados de la aplicación de la Ley marcial solo puede hacerse efectiva por los Tribunales Militares y no por los magistrados civiles.

MuJER: A principios de 1957 el juez Hueyo apresura los trámites. Cita a su despacho al comisario Benedicto Cuello testigo del fusilamiento, al médico policial doctor Chiesa. Interroga al personal del policlínico San Martín.

WALSH: Su premura está justificada, Fernández Suárez, sintiéndose acorralado, recurre a los altos mandos miliares en busca de ayuda, se reúne con el interventor de la Provincia, Coronel Bonnecarrere, y con el propio General Aramburu. De esta reunión de alto nivel, surge la solución salvadora.

FERNÁNDEZ SuÁREZ: Solicito que la Justicia Militar entienda en la causa que se instruyó por ser de su exclusiva competencia ${ }^{88}$.

MuJER: El 30 de enero el juez militar, Teniente Coronel Abraham González, reclamaba la causa en estos términos:

JUEZ MILITAR: "Por tratarse de un hecho que cae dentro de la jurisdicción militar por "ratione material" como igualmente podría serlo en el supuesto de lo dispuesto en el Artículo $2^{\circ}$ del citado superior decreto número 10363, dado que en tal caso sería de estricta aplicación el artículo 108, inciso $1^{\circ}$ del Código de Justicia Militar...

EN OFF: Que nadie se equivoque. La Revolución Libertadora cumplirá inexorablemente sus fines.

JuEZ: La justicia civil resuelve mantener su competencia y solicita copia auténtica de los decretos que implantaron la Ley marcial así como también fecha y hora exacta de su vigencia.

${ }^{88}$ Añadido a mano, al margen: "FS: Y no por los magistrados civiles”. 
MuJER: Este exhorto reiterado con fecha 28 de febrero, no obtiene respuesta por parte de la Justicia Militar.

WALSH: El caso fue a la Suprema Corte de Justicia de la Nación que el 24 de abril de 1957 dictó uno de los fallos más oprobiosos de nuestra historia judicial, previo dictamen del Procurador General de la Nación, doctor Sebastián Soler.

DR. SOLER: "Del informe ${ }^{89}$ a fojas 24 se desprende que en oportunidad de los sucesos del 9 de junio de 1956, las fuerzas policiales actuaron con subordinación a las disposiciones y autoridades de carácter militar. Por ello corresponde declarar la competencia en la causa, del Sr. Juez de Instrucción militar, a quien se remitirán los autos”.

WALSH: La palabra de un civil pesa muy poco ante la justicia militar. Pero hay otra justicia y ante esa, quiero presentarme como acusador ${ }^{90}$. A un individuo, Livraga, se lo detiene un día en que están en vigencia las leyes ordinarias. No se lo acusa formalmente de nada pero todavía no hay delito en esa orden de detención: es cierto que le dan unos golpes; olvidémoslo. La persona que lo detiene es un funcionario civil, el Jefe de Policía de la Provincia. Es cierto que ese funcionario es, además, Teniente Coronel, pero, para el caso, es como si lo fuera. Este funcionario civil no puede actuar como autoridad militar sobre alguien a quien ha detenido en cuanto funcionario civil. Sin embargo, actúa. Lo manda matar, no es una ejecución lo que él ordena. Es un asesinato. Livraga, según declara el propio Fernández Suárez, fue detenido el 9 de junio a las 23 horas. La Ley marcial se promulga a las 0.32 del 10 de junio, según consta en el libro de locutores de Radio del Estado. Estos son hechos. Una ley no entra en vigencia hasta ser divulgada por los órganos oficiales del Estado. Supongamos que la mera promulgación de la Ley marcial, le diera a un Jefe de Policía, sobre todas las personas previamente detenidas en las comisarías, la misma autoridad ilimitada que Fernández Suárez ejerció sobre Livraga. Este señor puede, entonces, asesinar a todos los presos confinados a su custodia y luego -si el caso llega a plantearse- se "juzgado" (llamémoslo así) por sus colegas y camaradas embarcados en su misma facción y acaso culpables de similares hazañas. ¿Acaso no ha ocurrido así? ¿Acaso el juez militar sancionó a los responsables de la Operación Masacre?

\footnotetext{
89 Añadido a mano: "obrante”.

${ }^{90}$ Añadido a mano: “(1)”. 
LIVRAGA $^{91}$ : La clase que esa justicia representa se solidarizó con aquel asesinato, lo adoptó como hechura suya y no lo castigó, simplemente porque no está dispuesta a castigarse a sí misma.

$\mathrm{Las}^{92}$ torturas y asesinatos que precedieron y sucedieron a la masacre de 1956 son episodios característicos y no anecdóticos de la lucha de clases en la Argentina.

$\mathrm{El}^{93}$ caso Manchego, el caso Vallese, el asesinato de Méndez, Mussi y Retamar, la muerte de Pampillón, el asesinato de Hilda Guerrero, las diarias sesiones de picana en comisarías de todo el país, la represión brutal de manifestaciones obreras y estudiantiles, las inicuas "razzias" en los barrios ${ }^{94}$, son eslabones de una misma cadena, en la que una y otra vez la represión, al volverse más ciega y violenta está reconociendo su impotencia. Era inútil en 1957 pedir justicia para las víctimas de la Operación Masacre, como resultó inútil en 1958 pedir que se castigara al general Cuaranta por el asesinato del abogado Satanowsky, como ha sido inútil reclamar que se sancione a los asesinos y torturadores de tantos otros. Dentro del sistema, no hay justicia.

$\mathrm{El}^{95}$ caso que hemos contado hoy no es un hecho excepcional. Es un ejemplo más de que esa oligarquía, dominante frente a los argentinos y dominada frente a los extranjeros, se ve históricamente impulsada hacia el asesinato.

Habrá que tener esto en cuenta cada vez que se encare la lucha contra ella. No para imitar o duplicar sus hazañas, sino para no dejarse conmover por las sagradas ideas, los sagrados principios y, en general, las bellas almas de los verdugos.

Mujer: Agradecimientos: al doctor Jorge Doglia, exjefe de la división judicial de la policía de la provincia, exonerado por sus denuncias sobre este caso; al doctor Máximo von Kotsch, abogado de Juan Carlos Livraga y Miguel Giunta; a Leónidas Barletta, director del periódico Propósitos.

Walsh: A Edmundo A. Suárez, exonerado de Radio del Estado por darme una fotocopia del libro de locutores de esa emisora, que probaba la hora exacta en que se promulgó la ley marcial; al ex terrorista llamado "Marcelo" que se arriesgó a traerme información y que poco después fue atrozmente picaneado; al informante anónimo que firmaba "Atilas"; a la anónima "Casandra" de

\footnotetext{
${ }^{91}$ El texto mecanografiado, que especifica que habla "L[ivraga]”, está corregido a mano: “[Daniel] Bergolo”. Se refiere a uno de los actores, como en las anotaciones subsiguientes, de modo tal que se preveía que las distintas partes del parlamento -que corresponde al epílogo de 1969 del libro de Walsh- fuesen interpretadas sucesivamente por distintos miembros del elenco.

92 Anotación al margen: “Adhemar [Bianchi]”

${ }^{93}$ Anotación al margen: "Fernando [Gilmet], Alexis [Hintz] y Mujer".

${ }^{94}$ Tachado a mano y corregido: "las villas miseria".

${ }^{95}$ Anotación al margen, ilegible.
} 
nueve años que sabía todo; a Horacio Manigua, que me dio albergue; a los familiares de las víctimas. 